\title{
Een schip op het strand is een baken in zee
}

\section{Over de criminogene rol van bedrijven en overheden bij shipbreaking}

\author{
Jasmien Claeys \& Lieselot Bisschop
}

Shipbreaking is de ontmanteling van afgedankte schepen voor hergebruik van onderdelen en terugwinning van grondstoffen. De meerderheid van de schepen wordt met rudimentaire methodes afgebroken op Zuidoost-Aziatische stranden. Dit schaadt de gezondheid van de arbeiders en verontreinigt het milieu. Deze casestudy bestudeert shipbreaking als milieucriminaliteitsfenomeen en gebruikt de geïntegreerde statecorporate crimetheorie als analysekader. We focussen op Duitsland en Griekenland als herkomstlanden en Bangladesh als land van bestemming. Onze resultaten tonen aan dat een complex criminogeen samenspel van economische en politieke actoren op nationaal en internationaal niveau de shipbreakingsector maakt tot wat deze vandaag is.

\section{Inleiding}

Shipbreaking is het ontmantelen van schepen die het einde van hun levensduur bereikt hebben (Moen, 2008). Onderdelen worden hergebruikt en grondstoffen, voornamelijk staal, worden herwonnen uit het schroot. Jaarlijks wordt een duizendtal schepen afgedankt, waarvan de meerderheid verkocht wordt aan scheepssloopwerven in Bangladesh, India, Pakistan en China. Hoewel commerciële schepen een levensduur van 25 tot 30 jaar hebben (Stopford, 2009), worden ze in tijden van economische crisis veel sneller afgedankt. De kosten om een schip in gebruik te houden wegen dan immers niet op tegen de schrootwaarde ervan.

Schepen bevatten allerlei stoffen die toxisch zijn voor mens en milieu. Scheepsafbraak dient daarom met de grootste zorg te gebeuren (Litehauz, 2015). Slechts een kleine minderheid van de afgedankte schepen wordt in veilige en milieuverantwoorde omstandigheden afgebroken (Helfre, 2013; Mulinaris, 2016). De vaakst voorkomende en eveneens meest vervuilende methode is beaching (in dit artikel vertaald als 'stranden'). Hierbij worden schepen bij hoogtij en aan volle snelheid op een getijdenstrand gevaren. Vervolgens worden ze bij laagtij vanop het strand met rudimentaire methodes afgebroken (ILPI, 2016). In dit artikel wordt met de term shipbreaking enkel naar deze praktijk verwezen, niettegenstaande dat schepen ook via andere methodes afgebroken kunnen worden. In 2016 werden 668 schepen afgebroken op Zuidoost-Aziatische getijdenstranden, goed voor 87 procent van het wereldwijde slooptonnage. 43 procent hiervan was afkomstig van Europese eigenaars, waardoor Europa de belangrijkste export- 
markt voor end-of-lifeschepen naar Zuidoost-Aziatische sloopstranden is. 84 procent van de in 2016 afgedankte Europese schepen strandde in India, Pakistan of Bangladesh (Mulinaris, 2017).

De beachingmethode wordt vooral toegepast in Bangladesh, India en Pakistan, waar schepen blootsvoets worden ontmanteld, met talrijke (dodelijke) ongevallen tot gevolg (Alcaidea e.a., 2016; Heidegger e.a., 2016). Hoewel mensenrechtenschendingen veelvuldig voorkomen, focust deze analyse op de ecologische aspecten. Zware metalen, zoals cadmium, look, kwik, arseen, chroom en nikkel, lekken in de zandstranden (Litehauz, 2015). Olie, brandstoffen, ruim- en ballastwater verontreinigen het oceaanwater en de oceaanbodem. Elk schip bevat tonnen asbest die ongecontroleerd vrijkomen bij ontmanteling (EJAtlas, 2016). Carcinogene PCB's komen in hoeveelheden voor die ver boven de risicogrens van de Wereldgezondheidsorganisatie (WHO) liggen (Nøst e.a., 2015). Om plaats te maken voor de Bengaalse afbraakstranden werden reeds honderden hectaren mangrovewoud gekapt met grote gevolgen voor de biodiversiteit. Bovendien vormt beaching oneerlijke concurrentie voor scheepswerven die wel milieuverantwoord - dus duurder - schepen ontmantelen, waardoor een ecologisch voordeel een economisch nadeel wordt.

In dit artikel stellen we ons de vraag waarom dit stranden van schepen ongehinderd kan blijven doorgaan, ondanks de gekende ecologische en sociale impact. Shipbreaking is een typevoorbeeld van transnationale milieucriminaliteit waarbij de werkelijke kosten van afval worden geëxternaliseerd: schadelijke gevolgen worden verplaatst naar ontwikkelingslanden. We trachten shipbreaking als milieucriminaliteitsfenomeen criminologisch inzichtelijk te maken en te verklaren op basis van exploratief kwalitatief onderzoek. We analyseren de rol van diverse betrokken ondernemingen en overheden, met de geïntegreerde state-corporate crimetheorie (Kramer e.a., 2002) als raamwerk. Deze casestudy combineerde semigestructureerde expertinterviews en een documentenanalyse.

\section{Theoretisch raamwerk}

Het fenomeen shipbreaking is reeds vanuit juridische, toxicologische, economische en medische invalshoeken bekeken. Vooral de juridische en economische insteek is relevant in functie van onze zoektocht naar verklaringen voor dit fenomeen. In zijn juridisch pionierswerk over shipbreaking wees Puthucherril (2010) op de onmacht van de nationale overheid van India om een globaal fenomeen als shipbreaking te reguleren en op de gemiste kansen van de internationale conventies. ${ }^{1}$ Economisch onderzoek focuste op het belang van (het voortbestaan van) de sector voor de Zuidoost-Aziatische economie en tewerkstelling (Alam \& Faruque, 2014; Sarraf e.a., 2010; Yujuico, 2014). 
Criminologisch onderzoek over shipbreaking is er niet en dit artikel wil hieraan tegemoetkomen. Dit thema past immers perfect bij een kritisch criminologische invalshoek van crimes of the powerful of groene criminologie. Het past in het rijtje van lawful but awful transnationale schadelijke (bedrijfs)activiteiten (Passas, 2005). We vertrekken dus vanuit een ruime definitie van criminaliteit die ook niet-gecriminaliseerde sociaal schadelijke gedragingen omvat (Hillyard \& Tombs, 2004). Een inbreuk van wet- of regelgeving is hierbij niet vereist om van criminaliteit te spreken, omdat vanuit een kritisch criminologisch perspectief beargumenteerd wordt dat de daders van dergelijke criminaliteit vaak ook net degenen zijn die invloed kunnen uitoefenen op het wetgevingsproces (Hillyard \& Tombs, 2004; Passas \& Goodwin, 2004). Shipbreaking by beaching is immers vaak perfect legaal aangezien de mazen van de wet worden benut, maar is wel schadelijk voor milieu, mens en economie. We gebruiken de geïntegreerde theorie over state-corporate crime (Kramer e.a., 2002) als analysekader. In navolging van Bongers crime in the suites (1916) en Sutherlands white collar crime (1945 besteedt deze theorie aandacht aan hoe gedragingen of nalatigheden van politieke, sociale en economische elites binnen de context van overheidsorganisaties of bedrijven tot milieuschade en/of mensenrechtenschendingen leiden (Hall, 2015). Deze theorie gaat ervan uit dat economie en politiek dermate verweven zijn dat ze ook in het verklaren van criminaliteit nooit volledig los van elkaar kunnen worden gezien (Green \& Ward, 2004).

'State-corporate crimes are the illegal or socially injurious actions that result from a mutually reinforcing interaction between (1) policies and/or practices in pursuit of the goals of one or more institutions of political governance and (2) policies and/or practices in pursuit of the goals of one or more institutions of economic production and distribution.' (Kramer e.a., 2002, 271)

State-corporate crime is volgens deze geïntegreerde theorie het resultaat van het samen voorkomen van de motivatie om doelstellingen te bereiken, de (gepercipieerde) opportuniteiten om deze op legale of illegale wijze te bereiken en het gebrek aan effectieve sociale controle. In deze studie bekijken we hoe de drie centrale katalysatoren motivatie, opportuniteit en gebrek aan (informele en formele) controle op shipbreaking van toepassing zijn. We houden daarbij de rol van overheden en ondernemingen - afzonderlijk en in interactie - tegen het licht.

De criminogene relatie tussen overheid en bedrijfsleven kan binnen het raamwerk van state-corporate crime diverse vormen aannemen. Bij state-facilitated corporate crime laat de overheid na (omissie) om te reguleren of controleren omdat dit de gemeenschappelijke doelstelling van overheden en bedrijfsleven in het gedrang zou brengen. Bij state-initiated corporate crime vinden schadelijke bedrijfsactiviteiten plaats in opdracht van of met uitdrukkelijke goedkeuring van de overheid. Matthews (2006) voegde corporation-facilitated state crime toe en Lasslett (2010) op zijn beurt corporation-initiated state crime. Bij het eerste voorzien bedrijven in de middelen voor staten om illegale en/of schadelijke gedragingen te stellen of 
laten ze begaan. Bij het tweede misbruiken bedrijven hun economische macht om overheden illegale en/of schadelijke gedragingen te laten stellen.

Dit raamwerk focust bovendien zowel op horizontale relaties tussen economische en politieke instellingen als op verticale relaties tussen individuen (micro), organisaties (meso) en de politiek-economische context (macro). Onze analyse wordt op het macroniveau van het theoretisch model toegespitst, dat we uitsplitsen in een nationaal en een internationaal deel (Mullins \& Rothe, 2007). Het nationaal niveau is immers relevant maar tegelijk ontoereikend in een internationale sector als scheepvaart. Tegelijk zijn de nationale context en de interactie met mondiale ontwikkelingen van belang. Onze analyse reikt verder dan specifieke gebeurtenissen en probeert om de systemische oorzaak, namelijk de symbiose tussen overheid en bedrijfsleven, te ontrafelen om zo shipbreaking criminologisch inzichtelijk te maken en te verklaren (Tombs, 2012).

\section{Methode}

We hebben een exploratief kwalitatief onderzoek opgezet in de vorm van een casestudy (Yin, 2009). Deze casestudy werd voorafgegaan door een verkennend vooronderzoek, bestaande uit literatuuronderzoek en analyse van mediaberichtgeving. Dit vooronderzoek gaf enerzijds zicht op mogelijke respondenten voor de interviews en diende anderzijds als basis voor het trekken van een strategische steekproef van landen om het onderzoek geografisch en inhoudelijk af te bakenen (Leys e.a., 2010). Duitsland en Griekenland werden hieruit als belangrijkste herkomstlanden van afgedankte schepen geïdentificeerd en Bangladesh als belangrijkste importland. Duitsland en Griekenland waren in 2016 koplopers in het beachen, met respectievelijk 97 en 104 van de 668 gedumpte schepen op ZuidoostAziatische stranden (Mulinaris, 2017). Deze cijfers zijn niet louter te verklaren door de grote vloot van deze landen, aangezien 98 procent van alle Duitse en 92 procent van alle Griekse sloopschepen vorig jaar op een sloopstrand belandde (Mulinaris, 2017). De sloopstranden van Chittagong in Bangladesh verwerken qua tonnage het belangrijkste aandeel van end-of-lifeschepen (Heidegger e.a., 2016; NGO Shipbreaking Platform, 2017b). Omdat deze drie landen als de belangrijkste spelers beschouwd kunnen worden, beperkt onze casestudy zich tot schepen in Duits of Grieks eigenaarschap die afgebroken worden in Bangladesh. Deze landen zijn echter niet representatief voor andere landen omdat de nationale context grondig kan verschillen van land tot land en gebrek aan externe geldigheid net een van de nadelen van een casestudy is (Leys e.a., 2010). Via een ketenaanpak onderzoeken we de volledige weg die end-of-lifeschepen afleggen.

De eigenlijke casestudy bestond uit de documentenanalyse (literatuur, gespecialiseerde mediaberichtgeving, blogs, ngo-rapporten, bedrijfswebsites) gecombineerd met semigestructureerde interviews. Bij mediaberichtgeving en informatie van ngo's werd extra aandacht besteed aan de kwaliteit van de informatie. De juistheid van mediaberichtgeving kan twijfelachtig zijn en ngo's overdrijven soms de zekerheid van hun bevindingen of de ernst van bepaalde voorvallen in functie van 
hun doelstellingen. Daarom werd deze informatie niet opgenomen als er geen ondersteuning gevonden werd bij de respondenten of bij wetenschappelijke bronnen. Ook de bevindingen uit de documentenanalyse en expertinterviews werden steeds getrianguleerd met informatie verkregen uit de literatuurstudie.

De documentenanalyse omvatte acht overheidsdocumenten (internationale verdragen, beleidsdocumenten (Europese Commissie), rapporten), 43 onderzoeksrapporten en jaarverslagen van ngo's (Greenpeace, NGO Shipbreaking Platform, YPSA, BELA, Clean Shipping Network), VN organisaties (UNCTAD, UNEP, IMO) en online kenniscentra van gespecialiseerde internationale instellingen (IMO, ILO, WorldWatch), achttien datasets van open databases (zoals World Bank, Transparency International, Paris MoU), 73 artikelen van gespecialiseerde (maritieme en economische) media (German Dry Docks Magazine, ShippingWatch, Cayman Financial Review, Financial Times, World Maritime News) en tien blogposts van twee maritieme blogs: shippingfinance (Basil Karatzas) en shippingtoday (Olaf Merk).

Voor de semigestructureerde interviews ( $\mathrm{N}=14$; zie tabel 1 ) werd een strategische selectie van mogelijke respondenten gemaakt. Deze deskundigen werden ofwel bereikt door het contacteren van gespecialiseerde instellingen (universiteiten (bijv. East West University Bangladesh, University of Dhaka), Maritiem Instituut), ofwel na doorverwijzing via een andere respondent, die aldus als gatekeeper naar andere respondenten of bepaalde informatiebronnen fungeerde (Van Gemert, 2010). De deskundigen maritieme financiering zijn gecontacteerd via LinkedIn nadat hun naam in verschillende relevante media opdook. Dankzij de beperkte non-respons zijn we erin geslaagd om zowel respondenten uit de publieke sector (beleidsmakers en handhavingsautoriteiten) als respondenten uit de private sector (werkzaam in de maritieme sector) te betrekken, aangevuld met onderzoekers en ngo-medewerkers actief in dit domein.

Voorafgaand aan elk interview werd een topiclist opgesteld op basis van inzichten verkregen uit de literatuurstudie en documentenanalyse en afgestemd op de achtergrond van de respondent. Tien interviews verliepen face to face of via videoconference door middel van Skype of WhatsApp. Deze gesprekken werden opgenomen nadat hiervoor toestemming gegeven was en achteraf volledig getranscribeerd om analyse te vergemakkelijken. Omwille van trage internetverbindingen en grote tijdsverschillen werd met vier experts via e-mail gecommuniceerd. De taalbarrière leverde geen problemen op, alle anderstalige respondenten waren de Engelse taal voldoende machtig. Gezien de gevoeligheid van de informatie werden de interviews anoniem verwerkt. Er werd achteraf de mogelijkheid geboden om citaten na te lezen (King \& Horrocks, 2010). De transcripties van de interviews werden geanalyseerd met behulp van een thematische kleurencode. De thema's die gehanteerd werden, zijn gebaseerd op de katalysatoren van het state-corporate crimemodel (motivatie, opportuniteit en controle). 
Tabel 1 Respondenten: nummer, functie, land, aantal contacten, taal van de communicatie

\begin{tabular}{|c|c|c|c|c|}
\hline $\begin{array}{l}\text { Respon- } \\
\text { dent }\end{array}$ & Functie & Land & \# contacten & Taal \\
\hline 1 & $\begin{array}{l}\text { Maritieme consultant } \\
\text { \& docent }\end{array}$ & België & 6 & Nederlands \\
\hline 2 & $\begin{array}{l}\text { Onderzoeker \& docu- } \\
\text { mentairemaker }\end{array}$ & Bangladesh & 3 & Engels \\
\hline 3 & Ngo-medewerker & België & 2 & Engels \\
\hline 4 & Ngo-medewerker & België & 4 & Engels \\
\hline 5 & Ngo-medewerker & België & 1 & Engels \\
\hline 6 & $\begin{array}{l}\text { Onderzoeker \& } \\
\text { docent }\end{array}$ & Bangladesh & 5 & Engels \\
\hline 7 & $\begin{array}{l}\text { Medewerker havenka- } \\
\text { piteinsdienst }\end{array}$ & België & 1 & Nederlands \\
\hline 8 & Ngo-medewerker & Bangladesh & 2 & Engels \\
\hline 9 & $\begin{array}{l}\text { Medewerker havenka- } \\
\text { piteinsdienst }\end{array}$ & België & 1 & Nederlands \\
\hline 10 & Beleidsmaker milieu & Europa & I & Engels \\
\hline 11 & Beleidsmaker afval & België & I & Nederlands \\
\hline 12 & $\begin{array}{l}\text { Deskundige maritieme } \\
\text { financiering }\end{array}$ & Zwitserland & 5 & Engels \\
\hline 13 & $\begin{array}{l}\text { Deskundige maritieme } \\
\text { financiering }\end{array}$ & New York & 3 & Engels \\
\hline 14 & $\begin{array}{l}\text { Deskundige afvalmana- } \\
\text { gement }\end{array}$ & Europa & 2 & Engels \\
\hline
\end{tabular}

\section{Resultaten}

Een schip op een sloopstrand heeft een complexe weg afgelegd met rederijen, chartermaatschappijen, scheepssloopwerven, benificial-ownerstaten en importstaten als hoofdrolspelers. We hebben het samenspel van actoren in figuur 1 proberen samen te vatten. De rol van elke actor wordt verderop besproken. We analyseren de motieven, opportuniteiten en controle op nationaal en internationaal vlak.

\section{Motieven}

- Een zinkend schip in internationale wateren

Er spelen wijdverspreide belangen bij de beslissing wanneer en waar een schip wordt gesloopt (Yujuico, 2014). Hierbij springt de verwevenheid van de scheepvaart met de wereldhandel en de financiële markten in het oog (Colibasanu, 2017). Er is momenteel sprake van een internationale maritieme crisis, waardoor de onderlinge concurrentie op de spits is gedreven en waarbij ook de maritieme financieringswijze niet over het hoofd gezien kan worden. 


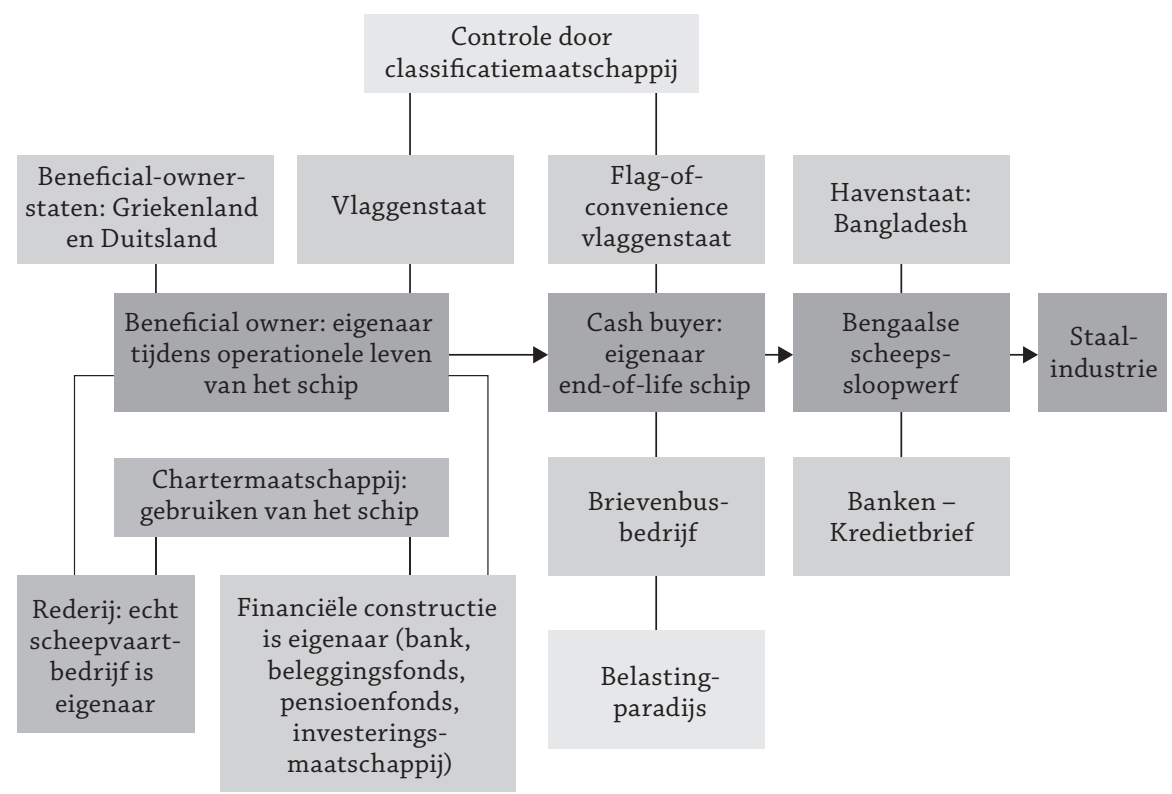

\section{Figuur 1 Opportuniteitsstructuur met actoren formele controle}

De huidige maritieme crisis is het gevolg van de mondiale economische crisis, die drie verschillende effecten heeft gehad op de maritieme wereld. Ten eerste werd geld lenen goedkoper, waardoor rederijen in nieuwe en grotere schepen investeerden, met als extra stimulans het diepere Panamakanaal (Karatzas, 2017; Osman, 2017). Het resultaat hiervan is een zelfgeïnduceerd overaanbod aan schepen (Hoffman e.a., 2016). Ten tweede zorgde diezelfde economische crisis in combinatie met het overaanbod ervoor dat vrachtprijzen lager kwamen te liggen dan de operationele kosten (Gronholt-Pedersen, 2016; Dann e.a., 2015). Hierdoor lag in 2016 ongeveer 30 procent van de wereldvloot 'droog' (Merk, 2016b). Ten derde stegen de staal- en olieprijzen ten gevolge van de economische crisis, waardoor het aantrekkelijker werd om schepen als schroot te verkopen. De wereldwijde crisis in de scheepvaartsector leidt zo tot het afdanken van recordaantallen schepen ruim voor hun operationele end-of-lifestatus.

Bovendien wakkert de concurrentiestrijd investeringen in nieuwe grotere schepen aan, waardoor oudere schepen vroegtijdig worden afgedankt (R7). De (Europese) scheepvaartindustrie staat het water aan de lippen door concurrentie met meer ondernemingsvriendelijke regio's (Kristiansen, 2017) en lobbyt bij overheden om de sector te helpen, verwijzend naar jobs en bruto nationaal product (bnp) (Pico, 2017).

Tot slot speelt de maritieme financieringssector een cruciale rol binnen de 'zeer versnipperde scheepvaartsector' (R7). Scheepseigenaars zijn vaak banken of fondsen die streven naar return on investment en weinig affiniteit hebben met de 
scheepvaartsector (Karatzas, 2015; Richter, 2017a). Overheden, waaronder de Duitse (infra), maakten scheepvaartinvesteringen fiscaal aantrekkelijk om de scheepvaartsector te stimuleren en extern kapitaal aan te trekken (Merk, 2016b; Dougherty, 2006; Kravets \& Kravets, 2014). Veel van deze financiering ging echter naar onstabiele partners die terug uit de markt verdwenen. Terwijl de rederij vroeger instond voor het operationeel management, de bevrachting en de bemanning, worden schepen vandaag gecharterd (Stube, 2016). Ook deze chartermaatschappijen kennen moeilijke tijden, zoals het recente faillissement van het Koreaanse Hanjin Shipping, de zevende grootste containerchartermaatschappij ter wereld, illustreert (Jefferson, 2017). De internationale overcapaciteit, veroorzaakt door de maritieme crisis en de onderlinge concurrentie, zorgt ervoor dat de scheepvaartinvesteringen kopje-onder gaan in plaats van het verwachte hoge rendement op te leveren. Om het kapitaal van de investeerders te redden moeten de managers van de fondsen zoveel mogelijk geld recupereren via scheepsafbraak.

\section{- De nationale context: geld als gemeenschappelijke noemer}

\section{- Duitsland}

Sinds 2004 kent Duitsland Kommanditgesellschaften (KG’s) waarbij privé-investeerders via een beleggingsfonds scheepseigenaar zijn. Deze fondsen worden gemanaged met het oog op hoge winsten, zonder persoonlijke betrokkenheid bij de scheepvaartsector (R1, R12). In 2013 werden 130 van deze KG's failliet verklaard en nog eens 400 schepen werden bestempeld als risicofondsen (Kravets \& Kravets, 2014). De gevolgen bleven niet uit. Zo strandden in 2016 negen schepen van eenzelfde Duits beleggingsfonds in Bangladesh (Krigslund, 2017). Respondent 3 zegt hierover: 'The bill for the ship owners' and investors' greed for profit is paid by workers and the environment.' Curatoren verkopen schepen uit bad loans en failliete KG-fondsen voor de hoogste sloopprijs om het verlies voor investeerders (institutionele pensioenfondsen, investeringsfondsen en grootbanken) en overheden te beperken (Richter, 2017a; Vogdrup-Schmidt, 2017). De tweedehandsmarkt is geen optie vermits deze prijzen laag staan door de overcapaciteit en reders net vanwege die overcapaciteit schepen van de markt willen halen.

Bovendien lijden niet enkel investeringsfondsen grote verliezen door de scheepvaartcrisis, ook de Duitse grootbanken (Deutsche Bank, Commerzbank) krijgen klappen (Colibasanu, 2017; Richter, 2017b). Deze banken zijn formeel gelinkt aan Duitse overheden via staatsgaranties en Duitse bedrijven via de raden van bestuur. De Duitse overheid heeft dus alle baat bij het welzijn van deze banken. Het monitoren van scheepvaartleningen is een prioriteit voor de Europese Centrale Bank gezien de potentiële impact op de economie (Jefferson, 2017).

\section{- Griekenland}

Griekse scheepseigenaars zijn, in tegenstelling tot de Duitse, geen investeringsfondsen, maar scheepvaartdynastieën waarbij het schip nog echt deel uitmaakt van de activa van het bedrijf (Karatzas, 2017; Dizard, 2015). Daarom werd de Griekse economische crisis door deze scheepvaartfamilies nauwelijks gevoeld, 
waardoor ze in staat waren Duitse KG-schepen op te kopen (Vogdrup-Schmidt, 2013). Ondanks deze gezondere financiële toestand strandden in 201627 Griekse schepen op Bengaalse stranden, waarvan er drie afkomstig waren van eenzelfde grote redersgroep die met puur privaat kapitaal is gefinancierd (NGO Shipbreaking Platform, 2017a).

De scheepvaartsector claimt 7,5 procent van het Griekse bnp te vertegenwoordigen, maar het meeste geld blijft in het buitenland plakken, waardoor 1 procent aannemelijker lijkt (Bergin, 2015). Toch houdt de Griekse overheid deze 'belangrijkste' economische sector de hand boven het hoofd met diverse grondwettelijk gegarandeerde belastingvoordelen, uit vrees voor een vlucht naar het buitenland.

\section{- Bangladesh}

Bangladesh is de favoriete bestemming voor sloopschepen omwille van goedkope arbeid $^{2}$, lakse wetgeving, lagere veiligheidsstandaarden en minder tot geen afvalverwerkingskosten (Alcaidea e.a., 2016; Chang e.a., 2010; Foysal, 2015). De afvalverwerkings- en arbeidskosten in westerse landen resulteren soms in een nettoverlies voor de rederij (R14). De financiële belangen van reders om te slopen in Bangladesh zijn dus hoog.

De motivatie van de Bengaalse overheid en Bengaalse ondernemingen is ook economisch van aard. De pullfactoren in het importland zijn drieledig: de hoge vraag naar extern staal, de werkgelegenheid en de overheidskomsten. Ten eerste heeft Bangladesh 350 staalwalserijen, maar geen staalertsmijnen, wat resulteert in een grote staalvraag en bijgevolg de hoogste sloopprijs per schip oplevert (Alcaidea e.a., 2016). Ten tweede voorziet de shipbreakingsector zo'n 220.000 Bengalen van een job (YPSA, 2012). Respondent 6: "It is said that "hunger is the best sauce". The poor masses don't hesitate to take risk of life to earn their bread. The industrialists take the opportunity to satisfy their ends, to utilize them for the industries.' De Bengalen hebben omwille van de precaire socio-economische context van het land weinig andere opties dan de dirty jobs te aanvaarden. Ten derde levert de sector jaarlijks 111 miljoen euro overheidsinkomsten op via diverse taksen (Foysal, 2015; Alam \& Faruque, 2014). Shipbreaking speelt dus een belangrijke rol in de Bengaalse economie. Bovendien hebben diverse politici persoonlijke belangen bij het niet-reguleren van de scheepssloopwerven (BSBA, 2015; NLC, 2009).

\section{Opportuniteit}

\section{- Vermeend Europees gebrek aan legale mogelijkheden}

Europese reders halen een gebrek aan capaciteit bij milieuverantwoorde scheepsafbraakwerven aan als reden voor de vlucht naar goedkopere Zuidoost-Aziatische werven: 'We don't know any demolition yards in Central Europe' (CEO van een Duitse rederij, in: Schlautmann, 2017). De afbraakcapaciteit is inderdaad beperkt tot ongeveer 900.000 ton per jaar, nauwelijks 10 procent van het slooptonnage

2 Een Bengaalse scheepssloper verdient tussen 3 en 5 euro per werkdag van 12 uur; een westerse arbeider verdient tot 230 euro per werkdag (CEG, 2007). 
van Bangladesh, India en Pakistan in 2016 (Bossard \& Nithart, 2016). Grote schepen kunnen enkel in Belgische, Nederlandse en Italiaanse werven terecht, Duitsland en Griekenland hebben zelf geen afbraakwerven (CEG, 2007). Er is echter veel 'slapende' capaciteit die niet aangesproken wordt door de concurrentie met de sloopstranden. De Europese Commissie (2016) baseert zich in haar overzicht van Europese scheepsafbraakwerven op een maximumcapaciteit die bepaald wordt door de hoogste jaarcapaciteit van de tien voorgaande jaren en verwijst slechts in een voetnoot naar de werkelijke theoretische maximumcapaciteit van de werven. Zo zou het Belgische Galloo Recycling 50.000 ton per jaar kunnen verwerken in plaats van de huidige 34.000 ton en de Nederlandse verwerkers KeppelVerolme en Scheepsrecycling Nederland respectievelijk 100.000 en 45.000 ton per jaar in plaats van de huidige 52.000 en 9.300 ton (Europese Commissie, 2016). Een Europees capaciteitsgebrek blijkt dus vooral een drogreden te zijn om de keuze voor Bangladesh voor zichzelf en de buitenwereld te verantwoorden.

\section{- Bengaalse corruptie en publiek-private symbiose}

Bangladesh kent een woelige politieke geschiedenis met conflicten tussen federale en lokale overheden en politiek geweld waarbij tientallen doden vielen (T.J., 2015; The Economist, 2016). Die onstabiele politieke situatie is om verschillende redenen een cruciale facilitator voor de actuele shipbreakingpraktijk. Wijdverspreide corruptie leidt tot fraude met certificaten en vergunningen (Heidegger, 2016a; Bhuiyan, 2010). De regering maakt het milieu-inspecteurs erg moeilijk om hun werk uit te oefenen (Rahman \& Mayer, 2016). Respondent 8 zegt hierover: 'It is very challenging. There is a lot of corruption and it feels like meeting with giants.'

Bovendien kopen zakenmannen zich in het (lokale) politieke leven in, zodat ze hun bedrijfsactiviteiten kunnen beschermen (Amundsen, 2014; Ketels, 2014): 'Businessmen to businessmen have a connection, direct or indirect. This professional relation may also have an influence when they are in the chair to make a decision' (R8). Diverse politici, zoals de leider van de Bangladesh Nationalist Party (BNP) Aslam Chowdhury, voormalig parlementslid Quasem Master en voormalige burgemeester van Chittagong, Monjurul Alam Monjo, zijn rechtstreeks bij de scheepssloopwerven en staalwalserijen betrokken (bdnews24.com, 2016; BSBA, 2015; NLC 2009). Sommige politici zijn zelf werfeigenaar en andere zetten hun directe familieleden aan het roer. Zakenmensen hebben politieke macht omdat ze politici helpen verkozen worden (EJAtlas, 2016; Rahman \& Mayer, 2016). De verwevenheid van politieke en zakelijke carrières leidt ertoe dat het uitwerken en handhaven van regelgeving voor de shipbreakingsector een onbegonnen zaak is: 'You have many people that are closely tied to the shipping industry regulating the shipping, they are helping each other, you have many revolving doors' (R4).

\section{- Internationale draaideurproblematiek}

Zowel de International Maritime Organization (IMO), een VN-agentschap, als de Europese Commissie (EC) kenmerkt zich door zogenaamde revolving doors, een belangrijk onderdeel van de opportuniteitsstructuur van de huidige ship- 
breakingpraktijk. Verschillende Commissieleden zijn er reeds van beschuldigd de EC-regels inzake de afkoelingsperiode niet te respecteren en te snel na hun functie binnen de private sector aan de slag te gaan (R10; Corporate Europe Observatory, 2015).

Binnen de IMO belichaamt Nikos Mikelis een cruciale draaideur. Hij stond mee aan de wieg van het Verdrag van Hong Kong inzake scheepsrecyclage (infra) en ging erna voor cash buyer GMS werken. Deze draaideur werd reeds duidelijk voordat Mikelis van kamp veranderde:

'Right before [Nikos Mikelis] left at the IMO, the IMO made a video saying that the IMO doesn't ban beaching and that they welcome improvements in Bangladesh and that they are very defensive of the beaching model. He has also represented Greece at the European Union, in the Council [while he was already working for GMS].' (R4)

Bovendien werd diezelfde Mikelis, niettegenstaande duidelijke belangenconflicten, door de IMO ingehuurd als consultant om samen met de ngo NORAD (Norwegian Agency for Development Cooperation) een project in Bangladesh te leiden, getiteld Safe and Environmentally Sound Ship Recycling in Bangladesh - Phase I (IMO, 2017b). Over dit project zegt respondent 5:

'They have made two reports on the economics of ship recycling in Bangladesh and on the environmental impact of the industry, both reports are extremely poor, none of them look at the cost of death, of disease, of workers without contracts, etcetera, etcetera. And the report on the environmental impacts just simply states that in times there needs to be an environmental impact and questions whether the pollution is actually coming from all the other industries which are around.'

Hieruit blijkt duidelijk dat het project niet de beoogde doelstellingen nastreeft. Bovendien wordt zowel de shipbreaking- als de financiële sector geruggensteund door een leger lobbyisten (Lobbyfacts.eu, 2016; Katzemich, 2016). Dit lobbywerk bemoeilijkt de totstandkoming van effectieve regelgeving.

\section{- Cash buyers als tussenpersoon}

Rederijen zijn strikt genomen geen eigenaar meer van gestrande sloopschepen. De mazen in de wet maken dit legaal. Ze verkopen het als tweedehandsschip aan een minder gekende rederij, die het na enkele operationele maanden heimelijk als sloopschip verkoopt (Bossard, 2016b). Of ze verkopen het aan een financiële constructie, waarna de schepen van deze papieren onderneming gecharterd worden of probleemloos verkocht worden aan een scheepssloopstrand (Heidegger, 2016b). Nagenoeg alle gestrande schepen komen via een vijftiental cash buyers, met Wirana en Global Marketing Systems (GMS) als grootsten (Fonseca, 2013; Alcaidea e.a., 2016; Yujuico, 2014). Deze ondernemingen profileren zich als duurzaam (R4) en kopen volledig cash schepen op, ongeacht de staat of locatie van het 
schip (Yujuico, 2014; Heidegger e.a., 2015; Alcaidea e.a., 2016; Fonseca, 2013). Cash buyers halen hun winst uit speculatie met de staalprijs (R4; R5) en hebben vaak zelf nauwe banden met scheepssloopstranden. Op papier is er geen enkele link tussen de cash buyer en de ondermaatse scheepsafbraak (Heidegger, 2016a). Het schip krijgt een andere naam om de integriteit van de oorspronkelijke eigenaar te beschermen, de vlag van een typische end-of-lifevlaggenstaat die nauwelijks controle uitoefent en strandt ongestoord in Bangladesh (zie figuur 1). Cash buyers verbergen zich bovendien achter brievenbusondernemingen in belastingparadijzen (o.a. advocatenkantoor Mossack Fonseca), waardoor ze erin slagen zelf ook grotendeels anoniem te blijven (Bossard e.a., 2016b; Fonseca, 2013; Heidegger e.a., 2015; Merk, 2016d; Moncayo, 2016; Schlautmann, 2017). Zonder cash buyers zou het voor rederijen veel moeilijker zijn om de verantwoordelijkheid voor de gestrande schepen van zich af te schuiven. Zo zei de CEO van een van Duitslands grootste rederijen vorig jaar 'our ships were all sold to trading buyers in Asia', nadat de schepen op sloopstranden beland waren (Schlautmann, 2017). Verschillende rederijen, waaronder ook de Belgische, hebben via dergelijke constructies schepen aan scheepssloopstranden verkocht (Bossard e.a., 2016a).

\section{- Banken in de grijze zone}

Hoewel veel ethische codes van banken vermelden dat ze niet met ondermaatse sloopwerven samenwerken, verlenen ze hun toch documentair krediet (Van Gelder e.a., 2012). Hierbij opent de sloopwerf een krediet bij een bank, die zich via een kredietbrief ertoe verbindt het bedrag uit te betalen aan de bank van de rederij (of in de meeste gevallen van de cash buyer) als aan de voorwaarden voor betaling is voldaan. Niet enkel banken in de landen van bestemming maken zich schuldig aan het overtreden van de eigen ethische regels, zoals voor de State Bank of India en de Indian Overseas Bank het geval bleek (Helfre, 2013), maar ook de in Londen gevestigde Standard Chartered Bank schreef kredietbrieven en leningen uit voor de aankoop van end-of-lifeschepen aan de Kabir Steel-werf in Chittagong, Bangladesh (NGO Shipbreaking Platform, 2016). Indien de banken zich aan de ethische codes zouden houden, zou het voor de Bengaalse sloopstranden nagenoeg onmogelijk zijn om schepen op te kopen omdat ze er zelf niet kapitaalkrachtig genoeg voor zijn.

\section{Formele controle}

Wetgeving ontwikkelen en implementeren voor een internationale sector als de scheepvaart is geen sinecure. Bovendien hebben maritieme staten een dubbele bevoegdheid. Ze treden enerzijds op als vlaggenstaatautoriteit voor schepen die onder hun vlag varen, waar ter wereld deze zich ook mogen bevinden, en anderzijds als havenstaatautoriteit voor alles wat zich binnen hun territoriale wateren afspeelt (Stopford, 2009). Deze dubbele handhavingsbevoegdheid maakt implementatie van wetgeving complex. Daarenboven hebben diverse instanties die voor formele controle instaan belangrijke tekortkomingen. 
- IMO als wetgever op zee

De IMO (2017a) is het VN-orgaan dat verantwoordelijk is voor richtlijnen inzake maritieme veiligheid en vervuiling voor 176 lidstaten, waaronder Griekenland, Duitsland en Bangladesh. Er zijn verschillende redenen waarom economische belangen hierbij domineren. Ten eerste zijn internationale en nationale scheepvaartsectororganisaties vertegenwoordigd in de IMO-organen (Merk, 2016d; R4; R5; R11). De industrie is dus nauwer betrokken bij het besluitvormingsproces dan bij andere vergelijkbare internationale organisaties (Pape, 2016):

'Most people would agree that a butcher sells meat, but should not be in charge in formulating meat quality rules and controlling them. This would present a conflict of interest - and it might get people ill. Yet, this is exactly what happens in shipping.' (Merk, 2016c)

Ten tweede geeft de manier waarop de IMO gefinancierd wordt een belangrijke indicatie voor de mate waarin het VN-agentschap onafhankelijk kan opereren. De jaarlijkse bijdrage van elke lidstaat is gebaseerd op de grootte van diens koopvaardijvloot, waardoor de lidstaten met de grootste economische belangen in de scheepvaart ook de grootste bijdrage aan de werking van de IMO leveren (Pape, 2016).

Ten derde hebben diverse vlaggenstaten hun IMO-lidmaatschap, en dus hun handhavingsbevoegdheid, gedelegeerd aan private bedrijven die voor hun inkomsten afhankelijk zijn van de scheepvaartbedrijven (infra). Door dit belangenconflict stellen deze vlaggenstaatvertegenwoordigers niet altijd de belangen van de vlaggenstaat voorop (Merk, 2017).

Ten vierde is het VN-orgaan afhankelijk van de lidstaten voor de ratificatie, inwerkingtreding en handhaving van verdragen (Stopford, 2009), wat vooruitstrevende en effectieve wetgeving in de weg staat.

Tot slot heeft de IMO de reputatie weinig transparant te zijn en kritische stemmen te weren (Merk, 2016c). Over standpunten die tijdens vergaderingen door specifieke lidstaten worden ingenomen, mag niet worden gecommuniceerd in de media. Ook onze respondenten konden niet naar specifieke landen verwijzen: 'To be honest, I don't know if I can refer to explicit statements by $[\mathrm{X}]$ or [Y] in that regard' (R10). Journalisten die zich niet houden aan de strenge rapportagerichtlijnen worden bestraft: 'Megan Darby, news editor of Climate Home, has been banned from the IMO for two years for having published quotes from an MEPC44 meeting' (R4). Hierdoor is druk uitoefenen op overheden of ondernemingen via de media onmogelijk. Een kritisch opiniestuk van classificatiebureau Lloyd's over potentiële belangenconflicten binnen de IMO inzake het Verdrag van Hong Kong werd kort na publicatie offline gehaald, wellicht na druk van de IMO zelf (R4).

Deze kenmerken van de institutionele omgeving waarbinnen internationale scheepvaartregelgeving ontwikkeld wordt, tonen aan dat de scheepvaartindustrie 
in de mogelijkheid verkeert om haar private (economische) belangen te laten primeren op ecologische en sociale.

\section{- Shipbreaking in internationale verdragen}

Het Verdrag van Bazel inzake de beheersing van de grensoverschrijdende overbrenging van afvalstoffen en de verwijdering ervan van 1989 vereist voorafgaandelijke toestemming bij afvaltransporten, maar is niet van toepassing bij recyclagetransporten. Het Verdrag is echter wel van toepassing op een afgedankt schip dat nog kan varen (Beslissing VII/26). In de praktijk blijkt dit echter moeilijk toe te passen. Het Ban Amendement uit 1995, dat stelt dat gevaarlijk afval niet buiten OESO-landen mag belanden en er ook straffen aan verbindt, is nog niet in werking getreden.

In 2009 werd het Verdrag van Hong Kong betreffende de Veilige en Milieuverantwoorde Recyclage van Schepen (VHK) ontwikkeld. Inwerkingtreding is afhankelijk van ratificatie van voldoende landen met scheepscapaciteit en afbraakvolume en is bijgevolg nog niet voor morgen (IMO, 2017c). Ngo's bestempelen het als greenwashing (zich milieubewuster voordoen dan werkelijk het geval is) omdat niets vermeld wordt over afvalverwerking (Alcaidea e.a., 2016; Chang e.a., 2010; Moncayo, 2016; Rahman \& Mayer, 2016). Zelfs als het VHK in werking zou treden, valt het te betwijfelen of het iets zal veranderen aan de huidige shipbreaking praktijk:

'Do we really believe that an end-of-life flag such as Niue, a black-listed tax haven in the Pacific with less than 2000 inhabitants, a cash buyer who hides behind an anonymous post box company in the British Virgin Islands, and Bangladesh, a country unable to fulfil its international obligations for labour rights and environmental protection, will solve the shipbreaking crisis for the ship owners headquartered in the world's shipping hubs? That is the "solution" offered by the industry-driven Hong Kong Convention.' (R4)

De EU heeft de voorbije jaren eigen maritieme wetgeving ontwikkeld (Van Leeuwen \& Kern, 2013). De Verordening van het Europees Parlement en de Raad van 20 november 2013 inzake scheepsrecycling (1257/2013), en tot wijziging van Verordening (EG) nr. 1013/2006 of de Europese Verordening voor Scheepsrecycling (EVS) is echter nog niet in voege, waardoor end-of-lifeschepen voorlopig nog onder de afvaltransportregelgeving EVOA (Verordening (EG) nr. 1013/2006 van het Europees Parlement en de Raad van 14 juni 2006 betreffende de overbrenging van afvalstoffen) vallen. Dit stelt dat er geen transport van gevaarlijk afval mag plaatsvinden tussen Europese havens en niet-OESO-landen, ongeacht de eigenaar of vlaggenstaat van end-of-lifeschepen. Deze verordening vertrekt vanuit havenstaatjurisdictie (Alcaidea e.a., 2016; Moncayo, 2016; Yujuico, 2014), wat inhoudt dat Europese havens end-of-lifeschepen kunnen tegenhouden. De praktische toepassing van EVOA op schepen blijkt echter niet evident (infra). 'Everyone knows that the Waste Shipment Regulation [EVOA] is very easy to circumvent when you're a ship owner' (R10). De EVS vertrekt daarom vanuit een vlaggenstaatauto- 
riteit en kiest voor geautoriseerde scheepsrecyclingwerven binnen Europa, het certifiëren van scheepsrecyclingfaciliteiten buiten Europa en het monitoren van de Europese vloot (Alcaidea e.a., 2016; Heidegger e.a., 2015; Yujuico, 2014). Het bepalen van de straffen en de handhaving wordt overgelaten aan de lidstaten (R10). De Verordening treedt in werking zes maanden nadat de lijst van gecertifieerde scheepsafbraakwerven de gezamenlijke capaciteit van 2,5 miljoen ton overschrijdt of ten laatste op 31 december 2018 (Heidegger e.a., 2015). De EVS kan veelbelovend klinken, maar doordat zij enkel van toepassing is op schepen die onder een Europese vlag varen, stelt simpelweg omvlaggen naar een niet-Europese vlag hen vrij van deze wetgeving.

\section{- Havenstaatcontrole bij export}

De vigerende milieuwetgeving beschouwt end-of-lifeschepen als gevaarlijk afval en de exporterende havenstaat als bevoegde handhavingsautoriteit. Deze regeling beantwoordt echter niet aan de geglobaliseerde maritieme realiteit, waardoor het gemakkelijk is voor de rederijen om door de mazen van het wetgevend net te glippen:

'Voor Bazel en [EVOA] heb je altijd een autoriteit van uitvoer nodig. Stel dat het schip ergens op de oceaan zit tussen Europa en Amerika en op dat moment beslist de eigenaar "Oh, ik ga daarmee naar de sloop (...)", dan is er geen land van uitvoer, want je hebt geen autoriteit die bevoegd is voor het midden van de oceaan. Handhaven op basis van waar dat een schip vertrekt, is fout, omdat je geen rekening houdt met de realiteit (...) dat het schip een vlag vaart en dat het de vlag is die bevoegd is, (...) het is irreëel om dan te denken dat je iets kan veranderen.' (R11)

In theorie kunnen de handhavingsautoriteiten beslissen om een sloopschip aan de ketting te leggen als het naar een niet-OESO-land vertrekt, of naleving afdwingen via een bankgarantie. Er is zelden voldoende bewijs hiervoor (R7; R11). Wanneer schepen om economische redenen afgedankt worden, zien ze er niet als 'afval' uit. Bovendien kan de EVOA ontweken worden door voor het stranden nog een niet-Europese haven aan te doen (Moncayo, 2016; Yujuico, 2014):

'Wij hebben enkel zicht op de eerstvolgende Port of Call, daarenboven is het afvaren naar Chittagong niet verboden. Wij mogen enkel een schip dat als schrootschip wordt aangegeven, tegenhouden indien niet aan de wettelijke voorschriften wordt voldaan.' (R9)

Bij een beschadigd schip kan de reder verklaren dat het schip naar een herstelwerf vaart. Het hangt van de havenstaatcontrole af in welke mate deze verklaring gecontroleerd wordt. Sommige cash buyers leggen valse herstelcontracten voor aan de exportoverheid (R4; R5). Zelfs als het contract echt is, is er geen garantie dat de reder het naleeft. Er zijn geen zaken bekend waarbij reactief werd opgetreden omdat de exportstaat niet meer juridisch vast te stellen is als het schip reeds gestrand is (R11). 
Slechts in enkele gevallen werd de illegale export van een end-of-lifeschip tegengehouden. In 2002 werd de Italiaanse tanker Sandrien door de Amsterdamse havenstaatcontrole aan de ketting gelegd voor herstel. Tijdens die herstelwerken kwam de Nederlandse milieu-inspectie via Greenpeace (R4) te weten dat het schip ondertussen verkocht was voor afbraak (Galley, 2014; Moncayo, 2016). In 2008 werd het Franse vliegdekschip Clemenceau tegengehouden, onderweg van Toulon naar de scheepssloopstranden van Alang (India). Dit was het resultaat van de acties van Greenpeace, Ban Asbestos en Indische ngo's. Beide schepen werden tegengehouden na een beslissing van de Raad van State, die stelde dat export in strijd was met de EVOA (Moen, 2008; Moncayo, 2016). In 2012 werd de Northern Vitality in het Duitse Wilhelmshaven tegengehouden en in 2014 het Japanse autodekschip Global Spirit in de haven van Antwerpen. In beide gevallen waren de autoriteiten getipt door NGO Shipbreaking Platform (Heidegger e.a., 2015). In april 2017 werd de Tide Carrier in Noorwegen tegengehouden, eveneens na tips van ngo's (Waste Management World, 2017; R4; R5). Deze beperkte casussen tonen enerzijds aan hoe moeilijk het is voor havenstaatautoriteiten om een sloopschip tegen te houden op basis van de EVOA en anderzijds hoe belangrijk de rol van ngo's (infra) hierin is.

De zaak Clemenceau is bovendien des te opmerkelijker omdat het vliegdekschip oorspronkelijk eigendom was van het Franse ministerie van Defensie. In het arrest van de Franse Raad van State stond te lezen dat de beslissing van de Franse minister van Defensie de wetgeving overtrad. Hieruit blijkt niet enkel de duidelijk tegengestelde rol die twee publieke partijen - Franse marine en milieu-inspectie behorend tot dezelfde overheid vervullen, maar ook het criminele aandeel van Europese - overheden in de huidige shipbreakingpraktijk. Het is des te schrijnender dat het hier om een schip in overheidseigendom ging.

\section{- Havenstaatcontrole bij import (Bangladesh)}

Hoewel Bangladesh lid is van het Verdrag van Bazel, wordt de procedure van voorafgaandelijke toestemming zelden toegepast. Ook de eigen milieuwetgeving wordt nauwelijks gehandhaafd (R8). Er wordt druk uitgeoefend op de overheid door ngo BELA ${ }^{3}$ via het aanspannen van rechtszaken. Hierdoor bereikte de ngo een verbod op de import van enkele schepen, zoals de olietanker Alpha in 2007, het cargoschip Asia Union en de tanker Probo Koala in 2011 (Galley, 2014). BELA voert ook actie tegen de shipbreakingsector zelf. In 2009 heeft het Hooggerechtshof in de zaak BELA-Bangladesh beslist dat de overheid 37 van de toen ongeveer 60 scheepssloopwerven moest sluiten omdat ze zonder milieucertificaat werkten (R6). De werfeigenaars dienden echter een verzoekschrift in om de zaak te heropenen, waarna het oorspronkelijke vonnis afgezwakt werd. Respondent 8 reageert hierop met: 'The court system is not so much independent in Bangladesh. Now you can guess how they got the case re-opened.' De ban werd in maart 2011 opgeheven en de overheid kreeg twee maanden om de sector te reguleren (Banerjee, 2013). De overheid werkte in mei de Ship Breaking and Ship Recycling Rules 
(SBSRR) uit, een papieren tijger door een gebrek aan middelen, infrastructuur en personeel en gebrekkige coördinatie tussen bevoegde diensten (Alam \& Faruque, 2014; Rahman \& Mayer, 2016). Meer zelfs:

'The administration has legalised illegal ship-breaking yards by giving them permits. These yards fulfil only 10 per cent of the conditions outlined in the environmental clearances.' (Banerjee, 2013, al. 5).

Economische belangen blijven duidelijk primeren. Een ambtenaar bij het Bengaalse milieudepartement wijst op het moeilijke spanningsveld tussen milieu en economie in een precaire socio-economische context:

'Environment and development is our goal; we do not want environment only. That does not feed us. (...) We are poor and our people starve. We need work. When we consider the environment, we consider it so that industry does not hurt.' (Rahman \& Mayer, 2016, 126)

Tot slot kampen importlanden ook met valse pre-clearingcertificaten (R4) en zijn de corruptie en verwevenheid van politiek en industrie problematisch voor een effectieve handhaving (R8).

\section{- Flags of convenience}

Vlaggenstaatcontrole wordt verondersteld beter te beantwoorden aan de maritieme realiteit, maar blijkt evenmin effectief. De wezenlijke band tussen het schip en de vlaggenstaat - de staat onder de vlag waarvan het vaart - is een wettelijke vereiste (United Nations Convention on the Law of the Sea (UNCLOS), art. 61(1)), maar is in de praktijk ondergraven door de deregulering van de internationale handel (Ormond, 2009). Bijna driekwart van de schepen vaart vandaag onder de jurisdictie van een staat waarmee de reder geen enkele band heeft (UNCTAD, 2015). Deze open scheepsregisters bieden rederijen, tegen betaling, een alternatief voor registratie onder de vlag waar de onderneming is gevestigd. 'Er is geen enkele correlatie meer, er is niks meer tussen die twee, dat is een zuiver financiële regeling, die overheid krijgt geld om die vlag te laten gebruiken' (R7). Beide partijen winnen inderdaad financieel aan deze regeling: rederijen ontsnappen aan strengere vennootschapswetgeving, strengere vereisten voor de bemanning en zwaardere taxatie (Stopford, 2009) en de vlaggenstaten zien de inkomsten via hun scheepsregister omhooggaan. Panama heeft het grootste open scheepsregister, maar ook Mongolië, een land zonder kust, krijgt geld om zijn vlag 'te laten gebruiken' (R7). Omvlaggen - of flag hopping - is de maritieme variant van jurisdictie(s)hoppen (Heidegger e.a., 2015). De open registers maken omvlaggen gemakkelijk en hebben voordelige voorwaarden voor sloopregistraties (Alcaidea e.a., 2016). 'It is an illusion to think that these flags states will enforce regulation on ship recycling; the raison d'être of a large share of them is not to bother shipowners' (Merk, 2016d: 'It is the system, stupid' - al. 4). De praktijk toont inderdaad aan dat deze flags of convenience-staten slecht scoren op vlag van ratificatie en handhaving van de scheepvaartwetgeving (Alcaidea e.a., 2016), omdat ze 
anders het risico lopen dat de rederijen omvlaggen naar een andere - nog laksere - vlaggenstaat en dus inkomsten mislopen. Ongeveer 40 procent van de end-oflifeschepen die naar Zuidoost-Azië afvaren, verandert naar een flag of convenience. Dit laat toe dat scheepseigenaars anoniem blijven en reders moeilijker aansprakelijk kunnen worden gesteld (Pape, 2016). De EVS en het VHK zullen dus weinig effectief zijn, tenzij de wezenlijke band met de vlaggenstaat terug aangescherpt wordt (R11).

De laatste jaren is de aanwezigheid van kleine eilandstaten als vlaggenstaten opvallend (Heidegger e.a., 2015). Uit secundaire analyse van datasets van NGO Shipbreaking Platform, UNCTAD, Paris MoU en de International Chamber of Shipping blijkt dat Comoros en Saint Kitts and Nevis in 2016 het vaakst werden gebruikt bij end-of-lifeschepen op Bengaalse stranden, maar amper gebruikt worden tijdens het operationele leven van een schip. Beide vlaggenstaten hebben miljardenschulden (Rothe \& Friedrichs, 2015), kennen grote sociale problemen (armoede, hongersnood) en wijdverspreide corruptie en zijn afhankelijk van externe financiële hulp. Beide landen bieden speciale kortingen aan voor sloopregistratie, bijvoorbeeld slechts 0,15 euro/bruto ton in plaats van 0,60 euro/bruto ton. De scheepsregisteroverstap kan buitengewoon snel en gemakkelijk via agentschappen op diverse locaties, zonder dat ooit originele documenten voorgelegd moeten worden. Ze stellen geen vereisten aan de nationaliteit van de beneficial owner, de crew of het operationeel management. Zelfs het opzetten van een offshore constructie om op papier een wezenlijke band te kunnen aantonen, is onnodig (Heidegger e.a., 2015). Deze goedkope vlaggenstaten laten rederijen toe om het eigenaarschap van een schip structureel te verdoezelen (Heidegger, 2016a). Hieruit blijkt nogmaals dat overheden en rederijen samenwerken uit financieel gewin.

\section{- Gedelegeerde vlaggenstaatautoriteit}

Diverse vlaggenstaten - waaronder alle flags of convenience - besteden bij gebrek aan expertise binnenshuis hun verplichtingen uit aan private ondernemingen, in de praktijk meestal classificatiemaatschappijen (R7; R9). Classificatiemaatschappijen hadden oorspronkelijk tot taak schepen te keuren voor verzekeraars en waren non-profitorganisaties. Vandaag behoren technische inspecties inzake internationale verdragen, codes en protocollen in naam van de vlaggenstaat ook tot hun takenpakket. Doordat steeds meer staten zonder enige maritieme ervaring optreden als vlaggenstaten is de rol van toezichthouder in dienst van de overheid aanzienlijk toegenomen (Stopford, 2009). De link tussen classificatiemaatschappij en vlaggenstaat is, net zoals tussen reder en vlaggenstaat, onduidelijk, wat opnieuw voor problemen zorgt. De vlaggenstaatautoriteit van Antigua is in Duitsland gevestigd (ADOMS, s.d.; R4), die van Comoros in Bulgarije (Comoros Maritime Administration, 2016) en die van Saint Kitts and Nevis in het Verenigd Koninkrijk (St. Kitts \& Nevis International Ship Registry, s.d.). Omdat class hopping (veranderen van classificatiemaatschappij door rederijen) mogelijk is en vlaggenstaten hun taken aan meerdere classificatiebureaus delegeren, is er commerci- 
ele druk en competitie tussen de classificatiemaatschappijen ontstaan (Lagoni, 2007).

Dit alles heeft geleid tot een belangenconflict: de commerciële druk om reders aan te trekken versus de verantwoordelijkheid voor het degelijk uitoefenen van de gedelegeerde vlaggenstaatverantwoordelijkheid, waarbij financiële sancties voor de reders kunnen volgen (Chin, 2008; Stopford, 2009). Het verzekeren van veiligheidsstandaarden in een dergelijke competitieve omgeving heeft ertoe geleid dat de standaarden versoepeld werden (Lagoni, 2007), maar pogingen van de Europese Commissie en de beroepsorganisatie van classificatiemaatschappijen om standaarden de uniformeren faalden.

Doordat zowel de link tussen de rederij en de vlaggenstaat als de link tussen de vlaggenstaat en de classificatiemaatschappij ondergraven is, hebben de vlaggenstaten en de classificatiemaatschappijen er financieel belang bij om zo laks mogelijk met de wetgeving om te springen, omdat ze dan beide meer scheepsregistraties (en dus inkomsten) hebben. Hieruit blijkt opnieuw de verwevenheid van de economische belangen van overheden (vlaggenstaten) en ondernemingen (rederijen).

\section{Informele controle}

De sociale omgeving van de scheepvaartonderneming bestaat uit de media, de publieke opinie, sociale bewegingen, klanten (expediteurs en chartermaatschappijen), aandeelhouders en beleggers, financiële instellingen en verzekeraars, milieuorganisaties en ngo's, academici en onderzoeksinstellingen (Higgins \& White, 2016; White, 2008; Pink \& White, 2016). Deze derde-partijen situeren zich tussen de regelgevende partij (de overheid) en degene die onder de regelgeving valt (de scheepvaartsector) en kunnen de ondernemingen informeel monitoren (Higgins \& White, 2016). Deze vormen van informele controle zijn met wisselend succes toegepast op de shipbreakingsector.

\section{- De cruciale rol van ngo's}

Ngo's hebben de ervaring en technische kennis in huis die autoriteiten dikwijls ontberen, waardoor ze een belangrijke taak in informele controle hebben (Pink \& White, 2016, Higgins \& White, 2016). Ze kunnen informatie verspreiden waardoor ze het onderwerp onder de publieke aandacht brengen en het maatschappelijk bewustzijn vergroten (Bisschop, 2016). De in Brussel gevestigde NGO Shipbreaking Platform voert zowel op VN- als op EU-niveau actie en heeft adviseursstatus binnen de IMO. Ze werken ook nauw samen met de in Chittagong gevestigde ngo Young Power in Social Action (YPSA). NGO Shipbreaking Platform publiceert frequent persberichten, waarbij rederijen en werven bij naam worden genoemd en maakt jaarlijks een lijst op met worst dumpers. Ze spreken overheden aan op het gedrag van hun ondernemingen en spelen eveneens een rol in formele handhaving (supra), onder andere op basis van informatie van klokkenluiders bij ondernemingen (R4). De rol van BELA in formele controle werd hierboven reeds aangehaald. Hun rechtszaken zijn vaak gevoed door informatie van het milieude- 
partement, dat er door gebrek aan politieke wil vaak zelf niet in slaagt regelnaleving te bevorderen (Rahman \& Mayer, 2016). IJveren voor naleving van de wetgeving is niet zonder gevaar in een derdewereldland zoals Bangladesh, waar medewerkers van BELA en YPSA reeds verbaal en fysiek werden aangevallen (R8).

\section{- Mediaberichtgeving en publieke opinie}

De publieke opinie vormt een uitstekend drukkingsmechanisme om politieke en zakelijke actoren te stimuleren tot gedragsverandering (Higgins \& White, 2016; White, 2008). Negatieve publiciteit veroorzaakt reputatieschade bij de onderneming of overheid, wat vervolgens kan resulteren in verlies van klanten, aandeelhouders en kiezers (Fisse \& Braithwaite, 1983). Hoe effectief dit kan zijn, blijkt uit de Brent Spar-casus van 1995 (Zyglidopoulos, 2002). Shell koos ervoor om de afgedankte olieopslagboei Brent Spar te laten zinken (deepsea disposal), omdat dit volgens studies die ze lieten uitvoeren de meest praktische optie was, en kreeg er toestemming voor van de Britse overheid. Greenpeace wilde een milieuvriendelijkere oplossing, onder meer omdat het een precedent zou scheppen voor honderden andere platformen. Greenpeace riep op tot een boycot van Shell, die ook de politiek niet onberoerd liet. Politiek, bedrijven en ngo's bleven het oneens over de beste oplossing, maar de Brent Spar werd uiteindelijk voor de kust van Noorwegen ontmanteld omdat de druk van de publieke opinie te hoog werd. Er zijn echter diverse redenen waarom naming and shaming van ondernemingen slechts een geringe impact blijkt te hebben wanneer het gaat om schepen die eindigen op sloopstranden.

Negatieve publiciteit is immers pas een effectief middel tot gedragsverandering wanneer bedrijven nauw betrokken zijn bij de eindconsumenten. Hoewel sommige rederijen tot de grootste ondernemingen in de wereld behoren, blijken ze vaak onbekend bij burgers (Van Erp e.a., 2016). De eindconsument staat ver van de rederij, waardoor ngo-campagnes gericht tegen deze ondernemingen weinig commerciële druk zetten (Sköld \& Hougee, 2014). Rehmatulla (2016) verwoordt het zo:

'Shipping has dodged the bullet for various reasons, one of them being the public's lack of awareness of the industry. Unless you live next to a busy port, you probably don't think too much about the global shipping industry.'

Daarnaast zijn de schadelijke gevolgen van shipbreaking geëxternaliseerd, waardoor de Europese burger, die invloed kan uitoefenen op de Europese rederijen of op de lokale politiek, er niet wakker van ligt (Rehmatulla, 2016). Het valt op dat economische berichtgeving over de maritieme sector vaker gedeeld wordt door reguliere media dan ecologische feiten. Zo werd de aankondiging van het miljardenverlies van Maersk door Het Laatste Nieuws opgepikt (DPA \& Bloomberg, 2017), maar het shipbreakingschandaal niet (infra). Bovendien wordt milieuschade ten gevolge van shipbreaking niet acuut veroorzaakt, wat minder aantrekkelijk is voor de media dan bijvoorbeeld een gekapseisde olietanker. Langetermijnschade aan het ecosysteem is moeilijk te visualiseren, waardoor shipbreaking minder mediagevoelig is (Van Erp e.a., 2016). De berichtgeving over shipbreaking 
in Zuidoost-Azië blijft voornamelijk beperkt tot (dodelijke) ongevallen op de werven, waarbij dan terloops de milieu-impact ook vermeld wordt. In Griekenland is het trouwens zo dat de economisch machtige rederijen meebepalen wat in de media verschijnt (Hooper, 2015). Onafhankelijke rapporten over de scheepvaartsector zijn er onbestaande.

Scheepvaart is tot slot een weinig transparante sector. Wanneer de scheepvaartsector zich toch in de pers uitspreekt over beleid dat de sector dreigt te raken, halen ze aan dat dit voor een unlevel playing field zorgt en dus oneerlijk is (Kristiansen, 2016; Merk, 2016a). Ze schuiven de verantwoordelijkheid van zich af, zoals in andere gevallen van afvalfraude reeds werd vastgesteld (Huisman \& Van Erp, 2013).

Wat mogelijks meer impact heeft op het gedrag van ondernemingen is de reactie van investeerders op het uitbreken van een schandaal. Hooggeplaatste investeerders maken hun handen niet graag vuil aan vuile ondernemingen. Omdat de scheepvaartsector afhankelijk is van extern kapitaal (supra), kan dit een krachtig wapen in de strijd tegen ondermaatse scheepsafbraak zijn.

\section{- Hong Kong-nalevingscertificaat: een maat voor niets}

Classificatiebureaus verdienen momenteel geld met het uitreiken van voorlopige Hong Kong-nalevingscertificaten in afwachting van de inwerkingtreding van het verdrag. Deze certificaten hebben in de praktijk geen enkele waarde (R4). Het VHK stelt bijvoorbeeld dat er grond- en waterstalen voor laboanalyse moeten afgenomen worden om de vervuiling te meten, maar de Japanse classificatiemaatschappij Nippon Kaiji Kyokai, beter gekend als ClassNK, reikt in Alang (India) certificaten uit gebaseerd op een louter procedurele checklist en dus niet op de werkelijke prestaties (Marine Insight News Network, 2016). Veel ondermaatse scheepswerven zijn momenteel 'gecertificeerd' en rederijen verkondigen graag dat hun sloopschepen die werven als bestemming hebben. Ook lobbygroepen gebruiken dit als argument om ondermaatse werven op de EU-lijst te krijgen.

\section{- Zelfregulering door rederijen}

Zelfregulering is een vrijwillige aanpak, wat ook meteen de zwakte ervan aanduidt (Fisse \& Braithwaite, 1983). Het uitbreken van het Deense shipbreakingschandaal in oktober 2016 met 's werelds grootste rederij Maersk in de hoofdrol legde een bom onder de effectiviteit van zelfregulering in deze sector (Gronholt-Pedersen, 2016):

'When you have a company like Maersk that is famous, was famous until recently, for being a thought leader, the progressive ship owner who makes this kind of decisions, of course it's difficult, and it challenges, will the reputation angle work?' (R10)

De Deense rederij was lange tijd het toonbeeld van maatschappelijk verantwoord ondernemen binnen de scheepvaartsector door haar vooruitstrevende scheepsre- 
cyclagebeleid (Heidegger, 2016b). Maersk onderstreepte de samenwerking met state-of-the-art scheepssloopwerven in China, demonstreerde zijn visie over totale scheepsrecyclage - waarbij alle onderdelen en materialen hergebruikt worden - met moderne filmpjes en stelde expliciet tegen beaching te zijn: 'Ngo's argue that beaching must end now. We agree' (Heidegger, 2016b). In oktober 2016 kwam Danwatch, een onafhankelijk media- en onderzoekscentrum dat de invloed van bedrijven op mens en milieu onderzoekt, echter met bewijzen die de onderneming van haar voetstuk haalde (Nordahl \& Moller, 2016). Maersk kwam in Denemarken in een mediastorm terecht, de gefaalde zelfregulering werd beschouwd als greenwashing en het jarenlang zorgvuldig opgebouwde imago werd in een mum van tijd met de grond gelijkgemaakt.

De beknopte feiten: Maersk verkocht in 2009 veertien schepen aan een financiële constructie in Duitsland, het MPC Flottenfonds III, om ze vervolgens nog enkele jaren te charteren tot de schepen in 2014 op de Zuidoost-Aziatische sloopstranden belandden. Het chartercontract bevatte een sloopclausule waarin gestreefd werd naar de hoogste prijs beschikbaar op de afbraakmarkt, zonder enig ander criterium (Martinez, 2016b). De genoemde prijs komt overeen met de toenmalige schrootprijzen voor gestrande schepen in Zuidoost-Azië (Heidegger, 2016b). De rederij werd ervan beschuldigd onredelijke druk gezet te hebben op de Duitse eigenaar om de schepen te laten stranden (Merk, 2016d) en zou later in de pers verklaren dat zulke deals inderdaad niet gemaakt hadden mogen worden (Heidegger, 2016b).

Bijkomend werd in mei 2016 de drijvende olieproductie- en opslagtanker The North Sea Producer van Maersk rechtstreeks vanuit het Verenigd Koninkrijk naar Bangladesh gesleept en daar gestrand (Bossard \& Nithart, 2016; Heidegger, 2016a; Martinez, 2016a). Maersk beweerde dat het schip verkocht was voor verder operationeel gebruik, maar weigerde de naam van de koper te onthullen. Gezien de marktomstandigheden was het onwaarschijnlijk dat Maersk een koper gevonden zou hebben binnen de olie- en gassector (Heidegger, 2016a), waardoor er vermoed werd dat het schip verkocht werd aan een cash buyer en Maersk dus wist dat het gestrand zou worden. In dat geval is het bedrijf schuldig aan het illegaal uitvoeren van gevaarlijk afval onder de EVOA (Martinez, 2016a; Merk, 2016d).

De gevolgen bleven niet uit. Hapag-Lloyd, een van de voornaamste concurrenten van Maersk, benadrukte dat zij toegewijd blijven aan hun no beaching-beleid (Merk, 2016d). Investeerders, zoals de Nordea-bank en pensioenfondsen PFA en KLP, hadden luidop kritiek op de onderneming, beleidsmakers stelden zich vragen en de Deense overheid heeft een onderzoek geopend naar de feiten (Heidegger, 2016a; 2016b). Deze casus toont enerzijds aan hoe broos het vertrouwen op zelfregulering is, maar anderzijds ook hoe nefast het ontmaskeren van greenwashing voor de ondernemingsreputatie kan zijn. Bovendien blijkt ook het belang van deze reputatie voor de - al dan niet institutionele - investeerders. 


\section{Discussie}

Het state-corporate crimemodel helpt om het fenomeen shipbreaking op macroniveau inzichtelijk te maken en te verklaren aan de hand van de drie katalysatoren motivatie, opportuniteit en gebrek aan controle. Doorheen dit artikel werd duidelijk hoe de verschillende actoren en belangen op elkaar inhaken en hoe dit shipbreaking by beaching in de hand werkt.

De motivatie van overheden en bedrijven binnen de huidige shipbreakingpraktijk blijkt in één woord te vatten: geld. Internationale scheepvaart, scheepssloop en staalnijverheid zijn competitieve sectoren waarmee veel geld is gemoeid. De financiële motivatie is echter te differentiëren voor de drie onderzochte landen. In Duitsland zorgt de combinatie van de internationale scheepvaartcrisis met het unieke Duitse KG-financieringssysteem voor druk op de rederijen, die eigenlijk sectorexterne financiers zoals pensioenfondsen of beleggingsfondsen zijn die oorspronkelijk torenhoge winsten beoogden. De zelfgeïnduceerde overcapaciteit deed de investeringsbubbel uiteenspatten en doordat het dikwijls om institutionele investeringsfondsen gaat, is de algehele Duitse economie gebaat bij het overleven of beperken van de verliezen van deze fondsen. Het gaat met andere woorden om een samenspel tussen van de werkelijkheid verwijderde investeerders, voor wie vooral winst een rol speelt, en actoren die zich op en rond het water bevinden, voor wie vooral het minimaliseren van verliezen een rol speelt. Hierbij speelt ook de verwevenheid van politieke en ondernemingsdoelstellingen.

Griekenland kent een ander verhaal, aangezien het businessmodel op activabasis de Griekse scheepvaartsector minder gevoelig maakt voor de economische conjunctuur. Deze scheepvaartdynastieën kiezen louter voor de grootste winsten door Bangladesh als sloopbestemming te kiezen. Hier leidt de - vermeende - hoge bijdrage van de scheepvaartsector aan de nationale economie ertoe dat de overheid hun onevenredige belastingvoordelen toekent.

Bangladesh zelf doet ook economisch voordeel. De Bengaalse economie heeft nood aan extern staal, de werkgelegenheid die de sector creëert en belastinginkomsten die de activiteiten genereren. Ook hier speelt de overheid een sleutelrol in het in stand houden van de huidige situatie, doordat politici zelf (on)rechtstreeks bij shipbreaking betrokken zijn.

Overheidsactoren prioriteren dus stelstelmatig economische boven ecologische belangen en houden de huidige praktijk in stand om enerzijds de nationale economie te beschermen en anderzijds overheidsinkomsten te genereren via scheepsregistratietaksen of vennootschapsbelasting. Financiële instellingen en scheepvaartondernemingen van de exportlanden, eveneens gesteund door hun overheden, doen economisch voordeel of beperken hun verliezen.

De opportuniteitsstructuur van shipbreaking bestaat uit een complex en legaal samenspel van diverse actoren, die er een winstgevend businessmodel van hebben gemaakt. Bij shipbreaking by beaching worden zowel door ondernemingen als 
door overheden ecologisch en economisch onverantwoorde beslissingen genomen. Die beslissingen zijn niet crimineel in de juridische zin van het woord omdat de mazen van de wet worden gebruikt. Ze zijn echter vanuit een normatief perspectief wel als crimineel te bestempelen omwille van het ongecontroleerd vrijkomen van asbest, carcinogene PCB's en zware metalen zoals lood en arseen, verontreiniging van het oceaanwater door het lekken van olie, brandstoffen, ruimen ballastwater, en de oneerlijke concurrentie voor milieuverantwoorde afbraakwerven. Dit complexe samenspel tussen diverse publieke en private belangen is dus criminogeen te noemen. Dat legale label is kenmerkend voor state-corporate crime omdat de daders van deze criminaliteitsvorm net degenen zijn die deel uitmaken van of invloed kunnen uitoefenen op het wetgevingsproces (Passas \& Goodwin, 2004). Dit soort transnationale schadelijke bedrijfsactiviteiten daagt criminologen uit om buiten de geijkte nationale kaders te denken en de oorzaken in het samenspel van de economische en politieke sfeer zoeken.

In deze casestudy blijkt dergelijk criminogeen gedrag mogelijk doordat de asymmetrie in belastingsystemen en de mazen van het wetgevend net toelaten dat scheepseigenaars (beneficial owners) en cash buyers zich verschuilen achter goedkope vlaggenstaten en brievenbusbedrijven in belastingparadijzen. Financiële instellingen komen hierbij in beeld via het verschaffen van kredieten aan de scheepssloopwerven. Milieuverantwoorde scheepsafbraak in Europa wordt (onterecht) als ontoereikend gepercipieerd inzake capaciteit, maar is vooral duur door de hoge arbeids- en afvalverwerkingskosten.

Tegenover deze criminogene motieven en opportuniteiten staat bovendien een gebrekkig controleraamwerk. Informele controlemechanismen blijken zelden effectief in de scheepvaartsector. De externalisering van de milieuschade en de onbekendheid van de scheepvaartsector maken dat zowel kritische mediaberichtgeving als druk vanuit de publieke opinie ontbreekt. De afvalwetgeving is op endof-lifeschepen van toepassing, maar handhaving is nagenoeg onbestaand door de vele mazen in de wet. De nieuwe wetgeving lijkt vooral een symboolfunctie te vervullen: overheden geven aan dat shipbreaking belangrijk genoeg is om wetgeving te maken, maar beschermen tegelijkertijd de belangen van rederijen via achterpoortjes in de wetgeving. Ngo's spelen wel een rol van betekenis, zowel bij informele als bij formele controle, maar met jaarlijks honderden schepen die stranden in Zuidoost-Azië is hun werk een druppel op een gloeiende plaat. Bovendien staan toezichthouders daarbij soms op gespannen voet met andere overheidsactoren. Deze tegenstrijdigheid tussen publieke actoren bleek uit de case van het Franse vliegdekschip, waarbij de financiële belangen van de Franse marine met toezicht van de milieu-inspectie (en later de Raad van State) botsten.

Uit onze analyse op macroniveau kunnen we besluiten dat de drie katalysatoren van het state-corporate crimemodel (Kramer e.a., 2002) shipbreaking inzichtelijker maken en helpen verklaren. Een complex criminogeen samenspel tussen uiteenlopende economische en politieke actoren op nationaal en internationaal niveau (Mullins \& Rothe, 2007) maakt de shipbreakingsector tot wat deze vandaag is. De verschillende actoren en hun belangen haken naadloos op elkaar in en beïn- 
vloeden elkaar. Zo zorgt de economische motivatie ervoor dat overheden bereid zijn de opportuniteitsstructuur te verschaffen voor de ondernemingen, waarin ook het ontoereikend wetgevend kader een sleutelrol heeft. De onderlinge samenhang tussen motieven, opportuniteiten en controle en de interactie tussen publieke en private actoren is de kern. Aan de kant van de ondernemingen zijn er de rederijen, de financiële instellingen en investeerders, de cash buyers, de classificatiemaatschappijen en de sloopwerven zelf. Wat de betrokken overheden betreft zijn er Griekenland en Duitsland als de overheid van de beneficial owner, de diverse goedkope-vlaggenstaten, Bangladesh als importerende havenstaat en de overheden van de belastingparadijzen.

Shipbreaking neemt vooral de vorm aan van state-facilitated corporate crime, hoewel overheden regelmatig ook een meer actieve rol (state-initiated corporate crime) opnemen. Gezien de verwevenheid van banken en overheden is de stap naar corporation-initiated state crime niet zo veraf (Lasslett, 2010). Shipbreaking wordt veroorzaakt door het lage risico en de hoge winsten in een toegeeflijke - formele én informele - omgeving die systematisch economische doelstellingen boven de ecologische (en sociale) prioriteert. In hun interactie versterken overheden en ondernemingen elkaars ecologisch onverantwoorde gedrag om gemeenschappelijke economische doelstellingen te kunnen realiseren, waardoor een voedingsbodem voor milieucriminaliteit ontstaat en shipbreaking wordt genormaliseerd. Het proces dat het dumpen van schepen in ontwikkelingslanden verklaart, is daarom onlosmakelijk verbonden met de politieke en socio-economische context van de betrokken export- en importlanden en heeft dus systemische oorzaken (Tombs, 2012).

Toekomstig onderzoek zou kunnen uitzoeken of deze dynamieken zich ook op meso- en microniveau manifesteren. Op basis van voorliggend onderzoek kunnen we immers geen uitspraken doen over de verklarende mechanismen voor specifieke ondernemingen of overheden en individuen. Verder onderzoek zou ook verschillen met andere landen en regio's - wat betreft export en import - kunnen onderzoeken, zowel voor het handelen van ondernemingen als voor het handelen van overheidsactoren. Bovendien zou het interessant zijn om in te zetten op de rol van investeerders (banken, beleggingsmaatschappijen, pensioenfondsen) die wel gevoelig zijn voor imagoschade en de mate waarin via de publieke opinie druk op hen uitgeoefend kan worden.

Wat de aanbevelingen voor het beleid betreft kunnen we kort zijn, omdat de mazen in de wet hierboven ruimschoots toegelicht zijn. Een schip op het strand is een baken in zee. Het lijkt er echter niet op dat momenteel veel van deze gestrande schepen wordt geleerd. 


\section{Literatuur}

ADOMS (s.d.). Antigua \& Barbuda Department of Marine Services and Merchant Shipping. Retrieved from http://abregistry.ag/contact-us/on 18 April 2017.

Alam, S. \& Faruque, A. (2014). Legal regulation of the shipbreaking industry in Bangladesh: the international regulatory framework and domestic implementation challenges. Marine Policy, 47, 46-56.

Alcaidea, J.I., Piniella, F. \& Rodríguez-Díaza, E. (2016). The 'mirror flags': ship registration in globalised ship breaking industry. Transportation Research Part D, 48, 378-392.

Amundsen, I. (2014). 'Pay up and off you go!' Buying political positions in Bangladesh. In: T. Soreide \& A. Williams (eds.). Corruption, grabbing and development: real world challenges. Cheltenham: Edward Elgar Publishing, 140-147.

Banerjee, S. (2013). Ship-breaking industry back in business in Bangladesh. CounterCurrents. Retrieved from www.countercurrents.org/banerjee171113.htm on 4 May 2017.

bdnews24.com (2016). BNP leader Aslam Chowdhury barred from leaving country, say police. bdnews24.com, Bangladesh's First Internet Newspaper. Retrieved from http:// bdnews24.com/politics/2016/05/15/bnp-leader-aslam-chowdhury-barred-fromleavingcountry-say-police on 14 May 2017.

Bergin, T. (2015). The Greek shipping myth. How Greek shipowners talk up their role, and why that costs Athens millions. Reuters Investigates. Retrieved from www.reuters.com/ investigates/special-report/eurozone-greece-shipping/on 29 April 2017.

Bhuiyan, S.H. (2010). A crisis in governance: urban solid waste management in Bangladesh. Habitat International, 34, 125-133.

Bisschop, L. (2016). How e-waste challenges environmental governance. In: T. Wyatt (ed.). Hazardous waste and pollution. Detecting and preventing green crimes. Dordrecht: Springer, 27-44.

Bonger, W.A. (1916). Criminality and economic conditions. Boston: Little Brown.

Bossard, C. \& Nithart, C. (2016). Bulletin of information and analysis on ship demolition. In: C. Bossard \& J. Bonnemains (eds.). Shipbreaking (Vol. 46). Robin des Bois, 1-83. Retrieved from http://207.204.5.11/wp-content/uploads/shipbreaking46.pdf on 27 April 2017.

Bossard, C., Paduano, D. \& Nithart, C. (2016a). Bulletin of information and analysis on ship demolition. In: C. Bossard \& J. Bonnemains (eds.). Shipbreaking (Vol. 44). Robin des Bois, 1-90. Retrieved from http://207.204.5.11/wp-content/uploads/ shipbreaking44.pdf on 27 April 2017.

Bossard, C., Paduano, D., Vilarins, T. \& Nithart, C. (2016b). Bulletin of information and analysis on ship demolition. In: C. Bossard \& J. Bonnemains (eds.). Shipbreaking (Vol. 43). Robin des Bois, 1-85. Retrieved from http://207.204.5.11/wp-content/uploads/ shipbreaking43.pdf on 27 April 2017.

BSBA (2015). Members of Bangladesh Ship Breakers Association: particulars of the members. Bangladesh: Bangladesh Ship Breakers Association.

CEG (2007). Groenboek betreffende een betere ontmanteling van schepen (door de Commissie ingediend). COM(2007)269 def. Brussel: Commissie van de Europese Gemeenschappen. Gevonden op http://eur-lex.europa.eu/legalcontent/NL/TXT/PDF/?uri=CELEX: 52007DC0269\&from=en, laatst geraadpleegd op 29 april 2017.

Chang, Y.-C., Wang, N. \& Durak, O.S. (2010). Ship recycling and marine pollution. Marine Pollution Bulletin, 60, 1390-1396.

Chin, C.B.N. (2008). Cruising in the global economy: profits, pleasure and work at sea. New York: Routledge. 
Colibasanu, A. (2017). German exports, banks and the shipping industry. The global shipping industry hasn't recovered from 2008, and that's more bad news for German banks. Geopolitical futures. Retrieved from https://geopoliticalfutures.com/germanexports-banksand-the-shipping-industry/on 27 April 2017.

Comoros Maritime Administration (2016). The Maritime Administration of Union of Comoros. Retrieved from http://bihlyumov.com/contact/on 18 April 2017.

Corporate Europe Observatory (2015). The revolving doors spin again. Barroso II commissioners join the corporate sector. Exposing the power over corporate lobbying in the EU. Brussels: Corporate Europe Observatory.

Dann, B., Gold, M. \& Aldalur, A. (2015). Shipbreaking and toxins. In: A. Braestrup, L. Elder \& J. Neumann (eds.). The ocean and human rights. Washington: The Ocean Foundation, $1-44$.

Dizard, J. (2015 ). The expensive shipping news for Wall Street's smart money. Financial Times. Retrieved from www.ft.com/content/1bc40ec6-be7e-11e4-a341-00144feab7de on 29 April 2017.

Dougherty, C. (2006). Will German 'ship funds' create a glut of vessels? International Herald Tribune - The New York Times. Retrieved from www.nytimes.com/2006/10/25/ business/worldbusiness/25ihttranscol26.3279214.html on 28 April 2017.

DPA \& Bloomberg (2017). Miljardenverlies voor grootste bedrijf van Denemarken. Het Laatste Nieuws.

EJAtlas (2016). Dirty and dangerous shipbreaking in Chittagong, Bangladesh mapping environmental injustice. Environmental Justice Atlas - Environmental Justice Organisations, Liabilities and Trade.

Erp, J. van, Spapens, T. \& Wingerde, K. van (2016). Legal and extralegal enforcement of pollution by seagoing vessels. In: T. Wyatt (ed.). Hazardous waste and pollution. Detecting and preventing green crimes. Dordrecht: Springer, 163-176.

Europese Commissie (2016). European list of ship recycling facilities. Brussels. Retrieved from http://ec.europa.eu/environment/waste/ships/pdf/list_ship_recycling_facilities. pdf on 21 December 2017.

Fisse, B. \& Braithwaite, J. (1983). The impact of publicity on corporate offenders. Albany: State University of New York Press.

Fonseca, J. (2013). Growing importance of cash buyers and recycling. Retrieved from www. maritimeprofessional.com/blogs/post/growing-importance-of-cash-buyersandrecycling-12937.

Foysal, Q.O. (2015). Shipbreaking industries of Bangladesh: an overview and legal implication. University of Dhaka, Bangladesh.

Galley, M. (2014). Shipbreaking: hazards and liabilities. Dordrecht: Springer.

Gelder, J.W. van, Herder, A., Küpper, B. \& Spaargaren, P. (2012). Case study: Dutch banking groups and shipbreaking. A report for the Fair Bank Guide (Oxfam Novib, Milieudefensie, Amnesty International, FNV Mondiaal, Dierenbescherming and IKV Pax Christi). Amsterdam: Profundo Research and Advice, 1-93.

Gemert, F. van (2010). Kwalitatieve databronnen in de criminologie. In: T. Decorte \& D. Zaitch (eds.). Kwalitatieve methoden en technieken in de criminologie. Leuven: Acco.

Green, P. \& Ward, T. (2004). State crime. Governments, violence and corruption. London: Pluto Press.

Gronholt-Pedersen, J. (2016). Maersk container business sinks to quarterly loss. Reuters. Retrieved from www.reuters.com/article/us-maersk-results-idUSKBN12X13U on 27 April 2017.

Hall, M. (2015). Exploring green crime: introducing the legal, social and criminological contexts of environmental harm. London: Palgrave Macmillan. 
Heidegger, P. (2016a). Maersk involved in illegal toxic waste trafficking. Contaminated North Sea oil production and storage tanker ends up on the beach in Bangladesh. Press release. Retrieved from www.shipbreakingplatform.org/platform-news-maersk-involved-inillegal-toxicwaste-trafficking/on 28 April 2017.

Heidegger, P. (2016b). Maersk incited business partner to opt for worst breaking practices for 14 ships. Press release.

Heidegger, P., Jenssen, I., Mulinaris, N., Carlsson, F. \& Willcox, A. (2016). Annual report 2015. Brussels: NGO Shipbreaking Platform.

Heidegger, P., Jenssen, I., Reuter, D., Mulinaris, N. \& Carlsson, F. (2015). What a difference a flag makes. Why ship owners' responsibility to ensure sustainable ship recycling needs to go beyond flag state jurisdiction. Brussels: NGO Shipbreaking Platform.

Helfre, J.-F. (2013). Controversial shipbreaking dismantles stakeholder trust. Sustainalytics. Retrieved from www.shipbreakingplatform.org/shipbrea_wp2011/wp-content/ uploads/2013/06/Sustainalytics-Shipbreaking-Report-April-2013.pdf on 17 mei 2017.

Higgins, D. \& White, R. (2016). Collaboration at the front line: INTERPOL and NGOs in the same nest. In: G. Pink \& R. White (eds.). Environmental crime and collaborative state intervention. New York: Palgrave Macmillan, 101-116.

Hillyard, P. \& Tombs, S. (2004). Beyond criminology? In: P. Hillyard, C. Pantazis, S. Tombs \& D. Gordon (eds.). Beyond criminology: taking harm seriously. London: Pluto Press, 10-29.

Hoffman, J., Juan, W., Sirimanne, S. N., Asariotis, R., Benamara, H., Premti, A., Valentine, V., Youssef, F. (2016). Review of Maritime Transport 2016. In D. Barki \& L. DelezeBlack (Eds.): United Nations Conference on Trade and Development (UNCTAD).

Hooper, J. (2015). Greek shipping magnates remain buoyant as economic crisis deepens. The Guardian. Retrieved from https://www.theguardian.com/world/2015/jul/03/greek -shippingmagnates-economy-ordinary-people-suffer on 29 April 2017.

Hoque, A. \& Clarke, A. (2013). Greening of industries in Bangladesh: pollution prevention practices. Journal of Cleaner Production, 51, 47-56.

Huisman, W. \& Erp, J. van (2013). Opportunities for environmental crime: a test of situational crime prevention theory. British Journal of Criminology, 53(6), 1178-1200.

ILPI (2016). Shipbreaking practices in Bangladesh, India and Pakistan. An investor perspective on the human rights and environmental impact of beaching. Oslo: International Law and Policy Institute.

IMO (2017a). Member states: International Maritime Organization.

IMO (2017b). Safe and environmentally sound ship recycling in Bangladesh - Phase I. Retrieved from www.imo.org/en/OurWork/Environment/SupportToMemberStates/ MajorProjects/Pages/Ship-recycling.aspx on 14 May 2017.

IMO (2017c). Status of multilateral conventions and instruments in respect of which the International Maritime Organization or its Secretary-General performs depositary or other functions. Retrieved from www.imo.org/en/About/Conventions/StatusOfConventions/ Documents/Status\%20\%202017.pdf.

Jefferson, C. (2017). Shipping crisis puts German banks under pressure. DW. Retrieved from www.dw.com/en/shipping-crisis-puts-german-banks-under-pressure/a -37230991 on 28 April 2017.

Karatzas, B. (2015). Smart investments in shipping. Paper presented at the 3rd Cayman Islands Shipping Summit 2015 (MARE FORUM), Grand Cayman.

Karatzas, B. (2017). Trade and shipping: the world is not flat anymore. Cayman Financial Review. Retrieved from www.caymanfinancialreview.com/2017/02/01/tradeandshipping-the-world-is-not-flat-anymore/on 28 April 2017. 
Katzemich, N. (2016). German lobbyists in Brussels: fighting the corner of German business interests. LobbyFacts.eu. Retrieved from https://lobbyfacts.eu/articles/03-02 -2016/germanlobbyists-brussels-fighting-corner-german-business-interests.

Ketels, G. (2014, 30 december). Shipbreaking: 'Recycling a ship is always dangerous.', Webisode. \#HEADABOVEWATER. Retrieved from http://www.dw.com/en/ shipbreaking-recycling-a-ship-is-always-dangerous/a-18155491, laatst geraadpleegd op 30 april 2017

King, N. \& Horrocks, C. (2010). Interviews In qualitative research. Los Angeles: Sage.

Kramer, R.C., Michalowski, R.J. \& Kauzlarich, D. (2002). The origins and development of the concept and theory of state-corporate crime. Crime \& Delinquency, 48(2), 263-282.

Kravets \& Kravets (2014). The rise and fall of the German 'one ship KG' financing model. Retrieved from www.kravets.de/kk-report/2014/10/14/rise-and-fall-of-one-ship-kgfinancing-ingermany on 28 April 2017.

Krigslund, N. (2017). Rickmers Group booked major deficit in 2016. ShippingWatch. Retrieved from http://shippingwatch.com/secure/carriers/article9542215.ece?utm_ content=2017-0501\%2015\%3A59\%3A46\&utm_medium=top\&utm_source=Feed on 1 May 2017.

Kristiansen, T. (2016, 22 december). This is the shipowners' EU agenda for 2017. Shippingwatch. Retrieved from http://shippingwatch.com/secure/carriers/article9241562. ece, laatst geraadpleegd op 1 mei 2017

Kristiansen, T. (2017). Tanker CEOs look with pessimism at 2017. ShippingWatch. Retrieved from http://shippingwatch.com/secure/carriers/Tanker/article9316765.ece on 28 April 2017.

Lagoni, N. (2007). The liability of classification societies (Vol. 9). Berlin: Springer.

Lasslett, K. (2010). Scientific method and the crimes of the powerful. Critical Criminology, 18, 211-228.

Leeuwen, J. van \& Kern, K. (2013). The external dimension of European Union marine governance: institutional interplay between the EU and the International Maritime Organization. Global Environmental Politics, 13(1), 69-87.

Leys, M., Zaitch, D. \& Decorte, T. (2010). De gevalstudie. In: T. Decorte \& D. Zaitch (eds.). Kwalitatieve methoden en technieken in de criminologie. Leuven: Acco, 173-198.

Litehauz (2015). Intertidal zone study. Copenhagen: Litehauz Maritime Environmental Consultancy.

Lobbyfacts.eu. (2016). ECTU - European Shippers' Council (ESC). Retrieved from LobbyFacts.eu on 14 May 2017.

Marine Insight News Network (2016). NGO Shipbreaking Platform: investigative journalists catch Maersk red-handed in Alang. Marine Insight. Retrieved from www. marineinsight.com/shipping-news/ngo-shipbreaking-platforminvestigativejournalists-catch-maersk-red-handed-alang/on 14 May 2017.

Martinez, N.J. (2016a). Maersk and the hazardous waste in Bangladesh: another Maersk ship is sailed to dangerous shipbreaking yard. Copenhagen: Danwatch.

Martinez, N.J. (2016b). Maersk and the shadowy deals. Leaked documents: Maersk imposed demand for irresponsible scrapping of fourteen ships. Copenhagen: Danwatch.

Matthews, R.A. (2006). Ordinary business in Nazi Germany. In: R.J. Michalowski \& R.C. Kramer (eds.). State-corporate crime. Wrongdoing at the intersection of Business \& Government. New Brunswick: Rutgers University Press, 116-133.

Merk, O. (2016a). Shipping's carbon emissions: time for smart regionalism? Retrieved from http://shippingtoday.eu/shipping_carbon_emissions/on 14 May 2017.

Merk, O. (2016b). The fatal bubble game of ports and shipping. Retrieved from http:// shippingtoday.eu/shipping-port-bubble/on 28 April 2017. 
Merk, O. (2016c). Could a foreign firm speak for a shipping nation? Retrieved from http:// shippingtoday.eu/foreign-firm-speak-shipping-nation/, laatst geraadpleegd op 14 mei 2017.

Merk, O. (2016d). No more beach parties for shipping. Retrieved from http://shippingtoday. eu/ship_recycling/on 14 May 2017.

Merk, O. (2017). The sad story of a small island state. Retrieved from http://shippingtoday. eu/sadstory/on 14 May 2017.

Moen, A.E. (2008). Breaking Basel: the elements of the Basel Convention and its application to toxic ships. Marine Policy, 32, 1053-1062.

Moncayo, G.A. (2016). International law on ship recycling and its interface with EU law. Marine Pollution Bulletin, 109, 301-309.

Mulinaris, N. (2016). NGO publishes 2015 list of all ships dismantled worldwide. Ship owners found to be irresponsible: data on shipbreaking practices in 2015 reveal appalling record. Press release.

Mulinaris, N. (2017). Platform publishes list of ships dismantled worldwide in 2016. European ship owners top the list of global dumpers: the EU must do more to reverse this scandal. Press release.

Mullins, C.W. \& Rothe, D.L. (2007). The forgotten ones: the Darfuri genocide. Critical Criminology, 15, 135-158.

NGO Shipbreaking Platform (2016). South Asia Quarterly Update - Update on shipbreaking in South Asia from the NGO Shipbreaking Platform. Press release.

NGO Shipbreaking Platform (2017a). List of all ships dismantled worldwide in 2016.

NGO Shipbreaking Platform (2017b). 2016 list of all ships scrapped worldwide - facts and figures.

NLC (2009). Where ships and workers go to die: shipbreaking in Bangladesh \& the failure of global institutions to protect worker rights. Pittsburgh, PA: The National Labor Committee.

Nøst, T.H., Halse, A.K.R.S., Borgen, A.R., Schlabach, M., Paul, A., Rahman, A. \& Breivik, K. (2015). High concentrations of organic contaminants in air from ship breaking activities in Chittagong, Bangladesh. Environmental Science \& Technology, 49, 11372-11380.

Nordahl, C. \& Moller, L.M.S. (2016). Maersk and the hazardous waste: 'Talk about the problems and you're fired'. Copenhagen: Danwatch.

Ormond, T. (2009). Enforcing EU environmental law outside Europe? The case of ship dismantling. elni Review, 1, 13-21.

Osman, Y. (2017). Shipping loans weigh down banks. Handelsblatt Global. Retrieved from https://global.handelsblatt.com/finance/shipping-loans-weigh-down-banks-674921 on 28 April 2017.

Pape, M. (2016). The IMO - for 'safe, secure and efficient shipping on clean oceans'. Members' Research Service. Brussels: European Parliamentary Research Service (EPRS).

Passas, N. (2005). Lawful but awful: 'legal corporate crimes'. The Journal of Socio-Economics, 34(6), 771-786.

Passas, N. \& Goodwin, N. (2004). A crime by any other name. In: N. Passas \& N. Goodwin (eds.). It's legal but it ain't right: harmful social consequences of legal industries. Ann Arbor: University of Michigan Press, 1-27.

Pico, S. (2017). This is the role shipping plays in the EU. ShippingWatch. Retrieved from http://shippingwatch.com/secure/carriers/article9395516.ece on 28 April 2017.

Pink, G. \& White, R. (2016). Collaboration in combating environmental crime - making it matter. In: G. Pink \& R. White (eds.). Environmental crime and collaborative state intervention. New York: Palgrave Macmillan, 3-19.

Puthucherril, T.G. (2010). From shipbreaking to sustainable ship recycling: evolution of a legal regime. Leiden/Boston: Martinus Nijhoff Publishers. 
Rahman, S.M.M. \& Mayer, A.L. (2016). Policy compliance recommendations for international shipbreaking treaties for Bangladesh. Marine Policy, 73, 122-129.

Rehmatulla, N. (2016). Emit now, pay later: the case of shipping and its GHG emissions. University College London Energy Institute Blog. Retrieved from http://blogs.ucl.ac.uk/ energy/2016/10/18/emit-now-pay-later-case-shipping-ghgemissions/\#more-4871 on 1 May 2017.

Richter, W. (2017a). Global shipping meltdown mauls German banks, retail investors, taxpayers. Wolf Street. Retrieved from http://wolfstreet.com/2017/02/10/globalshippingloans-meltdown-german-banks-retail-investors-taxpayers/on 28 April 2017.

Richter, W. (2017b). The slowdown in the shipping industry could cause Germany's banking system to crash. Markets BusinessInsider. Retrieved from http://markets.

businessinsider.com/commodities/news/slowdown-in-shipping-industry-couldcausegerman-banking-system-crash-2017-2-1001771424 on 28 April 2017.

Rothe, D.L. \& Friedrichs, D.O. (2015). Crimes of globalization (Vol. 6). London: Routledge.

Sarraf, M., Stuer-Lauridsen, F., Dyoulgerov, M., Bloch, R., Wingfield, S. \& Watkinson, R. (2010). Ship breaking and recycling industry in Bangladesh and Pakistan. The World Bank. Retrieved from http://documents.worldbank.org/curated/en/872281468114238957/ The-ship-breaking-and-recycling-industry-in-Bangladesh-and-Pakistanon 14 May 2017.

Schlautmann, C. (2017). The shame of Germany's ship owners. Handelsblatt Global. Retrieved from https://global.handelsblatt.com/companies-markets/the-shame-ofgermanys-shipowners-739162 on 29 April 2017.

Sköld, S. \& Hougee, M. (2014). Environmental opportunities for shipping. Sweden: Clean Shipping Index.

St. Kitts \& Nevis International Ship Registry (s.d.). Why flag with St. Kitts \& Nevis? Retrieved from www.stkittsnevisregistry.net/on 18 April 2017.

Stopford, M. (2009). Maritime economics. London: Routledge.

Stube, A. (2016). We will not stand by and wait for global regulation. Retrieved from www. maersk.com/en/the-maersk-group/sustainability/we-will-not-stand-by-and-waitforglobal-regulation on 18 April 2017.

Sutherland, E. (1945). Is 'white collar crime' crime? American Sociological Review, 10(2), 132-139.

The Economist (2016). Mass arrests in Bangladesh. Round up the usual suspects. The Economist. Retrieved from www.economist.com/news/asia/21700669spateassassinations-provokes-heavy-handed-response-round-up-usualsuspects?zid= 306\&ah=1b164dbd43b0cb27ba0d4c3b12a5e227 on 30 April 2017.

T.J. (2015). Why Bangladesh's politics are broken. The Economist. Retrieved from www. economist.com/blogs/economist-explains/2015/02/economist-explains-0 on 1 May 2017.

Tombs, S. (2012). State-corporate crime symbiosis in the production of crime and harm. State Crime, 1(2), 170-195.

UNCTAD (2015). Review of maritime transport 2015. Geneva: The United Nations Conference on Trade and Development.

Vogdrup-Schmidt, L. (2013). Greeks going after German ships from wrecked KG funds. ShippingWatch. Retrieved from http://shippingwatch.com/secure/carriers/ article5436515.ece on 29 April 2017.

Vogdrup-Schmidt, L. (2017). HSH Nordbank in balancing act following Hamburg Süd sale. ShippingWatch. Retrieved from http://shippingwatch.com/secure/carriers/ article9431333.ece on 28 April 2017. 
Waste Management World (2017). Ship arrested in Norway following disastrous flight to Asian recycling yard. Press release.

White, R. (2008). Crimes against nature. Environmental criminology and ecological justice. Devon: Willan Publishing.

Yin, R. (2009). Case study research: design and methods. Thousand Oaks (CA): Sage.

YPSA (2012). Benefits from ship breaking. Dhaka, Bangladesh: Young Power in Social Action.

Yujuico, E. (2014). Demandeur pays: the EU and funding improvements in South Asian ship recycling practices. Transportation Research Part A, 67, 340-351.

Zyglidopoulos, S.C. (2002). The social and environmental responsibilities of multinationals: evidence from the Brent Spar case. Journal of Business Ethics, 36(1), 141-151. 